Article

\title{
Tectus niloticus (Tegulidae, Gastropod) as a Novel Vector of Ciguatera Poisoning: Detection of Pacific Ciguatoxins in Toxic Samples from Nuku Hiva Island (French Polynesia)
}

\author{
Hélène Taiana Darius ${ }^{1, *,+}$ (D), Mélanie Roué ${ }^{2,+}$ (D) $^{\text {, Manoella Sibat }}{ }^{3}$ (D), Jérôme Viallon ${ }^{1}$, \\ Clémence Mahana iti Gatti ${ }^{1}$, Mark W. Vandersea ${ }^{4}$, Patricia A. Tester ${ }^{5}$, R. Wayne Litaker ${ }^{4}$, \\ Zouher Amzil $^{3}$ (D), Philipp Hess ${ }^{3}$ (D) and Mireille Chinain ${ }^{1}$ \\ 1 Institut Louis Malardé (ILM), Laboratory of Toxic Microalgae-UMR 241-EIO, P.O. Box 30, 98713 Papeete, \\ Tahiti, French Polynesia; jviallon@ilm.pf (J.V.); cgatti@ilm.pf (C.M.i.G.); mchinain@ilm.pf (M.C.) \\ 2 Institut de Recherche pour le Développement (IRD)-UMR 241-EIO, P.O. Box 529, 98713 Papeete, Tahiti, \\ French Polynesia; melanie.roue@ird.fr \\ 3 IFREMER, Phycotoxins Laboratory, F-44311 Nantes, France; manoella.sibat@ifremer.fr (M.S.); \\ zouher.amzil@ifremer.fr (Z.A.); philipp.hess@ifremer.fr (P.H.) \\ 4 National Oceanic and Atmospheric Administration, National Ocean Service, Centers for Coastal Ocean \\ Science, Beaufort Laboratory, Beaufort, NC 28516, USA; mark.w.vandersea@noaa.gov (M.W.V.); \\ wayne.litaker@noaa.gov (R.W.L.) \\ 5 Ocean Tester, LLC, Beaufort, NC 28516, USA; ocean.tester@gmail.com \\ * Correspondence: tdarius@ilm.pf; Tel.: +689-40-416-484 \\ + These authors contributed equally to this work.
}

Received: 25 November 2017; Accepted: 18 December 2017; Published: 21 December 2017

\begin{abstract}
Ciguatera fish poisoning (CFP) is a foodborne disease caused by the consumption of seafood (fish and marine invertebrates) contaminated with ciguatoxins (CTXs) produced by dinoflagellates in the genus Gambierdiscus. The report of a CFP-like mass-poisoning outbreak following the consumption of Tectus niloticus (Tegulidae, Gastropod) from Anaho Bay on Nuku Hiva Island (Marquesas archipelago, French Polynesia) prompted field investigations to assess the presence of CTXs in T. niloticus. Samples were collected from Anaho Bay, 1, 6 and 28 months after this poisoning outbreak, as well as in Taiohae and Taipivai bays. Toxicity analysis using the neuroblastoma cell-based assay (CBA-N2a) detected the presence of CTXs only in Anaho Bay T. niloticus samples. This is consistent with qPCR results on window screen samples indicating the presence of Gambierdiscus communities dominated by the species G. polynesiensis in Anaho Bay. Liquid chromatography-tandem mass spectrometry (LC-MS/MS) analyses revealed that P-CTX-3B was the major congener, followed by P-CTX-3C, P-CTX-4A and P-CTX-4B in toxic samples. Between July 2014 and November 2016, toxin content in T. niloticus progressively decreased, but was consistently above the safety limit recommended for human consumption. This study confirms for the first time T. niloticus as a novel vector of CFP in French Polynesia.
\end{abstract}

Keywords: ciguatera poisoning; ciguatoxins; Tectus niloticus; gastropods; Gambierdiscus polynesiensis; qPCR assays; CBA-N2a; LC-MS/MS

\section{Introduction}

Tectus niloticus Linnaeus, 1767 (Gastropoda, Trochoidea, Tegulidae), a large, herbivorous marine snail widespread throughout Southeast Asia and the Western Pacific, is commonly known as trochus or top shell [1-3]. It can be found in both intertidal and subtidal reef habitats, generally in high energy 
sections of the reef. The optimum depth for T. niloticus is between 0 and $15 \mathrm{~m}$, although individuals can be found as deep as $25 \mathrm{~m}[3,4]$. Juveniles are quite cryptic, but larger individuals are often found on tropical coral reef flats $[3,5]$. T. niloticus are herbivores and tend to eat turf algae and biofilm by grazing on corals and rocks $[6,7]$.

T. niloticus has been introduced to many South Pacific Islands and is usually fished artisanally for its shell, which is used to make traditional ornaments by indigenous people, as well as in the manufacture of mother-of-pearl buttons, which can be a valuable source of income for people in the Indo-Pacific region [2,6,8,9]. The shell is also used in cosmetics and paint $[3,10]$. In addition, T. niloticus meat represents a valuable source of protein for many communities in Asian, as well as Pacific Island Countries and Territories (PICTs) [6,11]. Primary harvesters of trochus shells include Indonesia, the Philippines and Thailand, while Japan, Hong Kong and Europe are the most important consumers $[10,12]$.

T. niloticus was introduced in French Polynesia from the Republic of Vanuatu as early as 1957 to establish a fishery [13], but due to abusive exploitation, a law was issued in 1988 to protect this resource through a permanent fishing closure. However, there are limited fishing seasons authorized by the government with size limits and set quotas for the trade of mother-of-pearl and for consumption by local populations [14].

In June 2014, a mass-poisoning outbreak involving nine tourists occurred in Nuku Hiva Island (Marquesas archipelago, French Polynesia) following the consumption of T. niloticus collected from Anaho Bay $[15,16]$. All patients exhibited clinical symptoms typical of ciguatera fish poisoning (CFP), i.e., gastrointestinal (vomiting/diarrhea), cardiovascular (bradycardia and hypotension) and neurological (asthenia/myalgia, paresthesias/dysesthesias/cold allodynia) disorders, as well as symptoms like burning/tingling sensation of the mouth and throat $[15,16]$. Of note were atypical features such as the rapid onset $(2 \mathrm{~h}$ ) and unusual severity of gastro-intestinal and neurological symptoms, which necessitated the hospitalization of six patients $[15,16]$.

CFP is a food-borne poisoning known to be caused primarily by the ingestion of coral reef fishes contaminated by potent neurotoxins, ciguatoxins (CTXs), originating from benthic dinoflagellates in the genus Gambierdiscus [17,18]. However, ciguatera poisoning incidents involving marine invertebrates such as giant clams (e.g., Tridacna maxima, Hippopus hippopus) or sea urchins (Tripneustes gratilla) are also currently reported in PICTs (French Polynesia, New Caledonia, Cook Islands, the Republic of Vanuatu, etc.) [19-22]. A recent study by Roué et al. (2016) provided confirmation that giant-clams (T. maxima) are actually able to bioaccumulate CTXs when exposed to Gambierdiscus cells [23].

Since T. niloticus are herbivores and commonly graze on epiphytic organisms or those growing on biofilms [7], they can potentially bioaccumulate marine biotoxins in their tissues, e.g., upon feeding on toxic micro-algae from benthic assemblages. The aim of this study was to assess the toxicity of T. niloticus specimens collected from the toxic area of Anaho Bay over a two-year period and compare the data with two other sites on Nuku Hiva Island, Taipivai and Taiohae Bays. In addition, quantitative polymerase chain reaction (qPCR) assays were used to identify dominant Gambierdiscus species present at the sampling sites, as well as in clonal cultures established from the field-collected material. Toxicological analyses were carried out using the neuroblastoma cell-based assay (CBA-N2a) to test for the potential presence of toxins in T. niloticus samples. In addition, liquid chromatography coupled to tandem mass spectrometry (LC-MS/MS) was used for both identification of ciguatoxin analogues and multi-toxin screening for a variety of other marine toxins. These include: neurologic shellfish toxins (NSP), i.e., brevetoxins ( $\mathrm{PbTX} 1$ to $\mathrm{PbTX} 10$ ), paralytic shellfish poisoning (PSP) toxins, i.e., carbamates (STX, NEO-STX, GTX1-GTX4), N-sulfocarbamoyl (GTX5, GTX6 and C1 toC4) and decarbamoyls (dcSTX, dcNEO, dcGTX1-dcGTX4); diarrhetic shellfish poisoning (DSP) toxins i.e., okadaic acid (OA), dinophysistoxins (DTXs), pectenotoxins (PTXs), azaspiracids (AZAs) and yessotoxins (YTXs); cyclic imines (fast action toxins (FAT)): gymnodimines (GYMs), spirolides (SPXs) and pinnatoxins (PnTXs). 


\section{Results}

\subsection{Abundance of Gambierdiscus spp. in Study Sites}

Gambierdiscus cells were collected from macroalgae, as well as from 18 window screen (WS) sampling devices deployed at three sites on Nuku Hiva Island during a field mission in November 2016 (Tables 1 and 2).

Manual cell counts revealed that macroalgal substrates yielded very low cell densities (i.e., $1.5 \pm$ 2.6 cells / $g$ of macroalgae) with cells being observed only in turf and Halimeda samples from Anaho Bay (Table 1). No Gambierdiscus cells were counted in Taipivai Bay, while no macroalgae have been found in Taiohae Bay.

Table 1. Densities ${ }^{1}$ of Gambierdiscus spp. found in macroalgal substrates in 3 distinct locations of Nuku Hiva Island.

\begin{tabular}{cccc}
\hline \multirow{2}{*}{ Site } & $($ (n) & \multicolumn{2}{c}{ Macroalgae } \\
\cline { 3 - 4 } & & Genus & Total $^{\mathbf{1}}$ \\
\hline Anaho & 8 & Turf, Halimeda & $1.5 \pm 2.6$ \\
Taipivai & 2 & Halimeda micronesica & 0 \\
Taiohae & - & NF $^{2}$ & - \\
\cline { 2 - 3 }${ }^{1}$ Densities counted manually and expressed in cells/g algal wet weight; ${ }^{2} \mathrm{NF}=$ not found.
\end{tabular}

Conversely, Gambierdiscus cells were collected from every sampling site using WS sampling methods. Ten semi-quantitative, species-specific qPCR assays were used to survey the WS samples for relative cell abundance and Gambierdiscus species distribution. Five species were detected including Gambierdiscus caribaeus, G. carpenteri, G. pacificus, G. polynesiensis and G. toxicus (Table 2). In contrast, Gambierdiscus australes, G. belizeanus, G. carolinianus, Fukuyoa ruetzleri, G. silvae and Gambierdiscus ribotype II were not detected in the WS samples.

Table 2. Semi-quantitative qPCR estimates of Gambierdiscus species composition identified from window screen sampling ${ }^{1}$ in Nuku Hiva Island.

\begin{tabular}{cccc}
\hline \multirow{2}{*}{ Species } & \multicolumn{3}{c}{ Location } \\
\cline { 2 - 4 } & Anaho Bay $\boldsymbol{n}=\mathbf{6}$ & Taipivai $\boldsymbol{n = 6}$ & Taiohae $\boldsymbol{n = 6}$ \\
\hline G. caribaeus & $<1 \%$ & $<1 \%$ & $<1 \%$ \\
G. carpenteri & $17 \%$ & $90 \%$ & $88 \%$ \\
G. pacificus & $<1 \%$ & $<1 \%$ & $<1 \%$ \\
G. polynesiensis & $82 \%$ & $10 \%$ & $10 \%$ \\
G. toxicus & $<1 \%$ & $<1 \%$ & $1 \%$ \\
Total cells & $\sim 2900$ & $\sim 415$ & $\sim 420$ \\
\hline
\end{tabular}

${ }^{1} 150 \mathrm{~cm}^{2}$ window screen.

G. polynesiensis was the predominant species detected in Anaho Bay, whereas G. carpenteri predominated in Taiohae and Taipivai Bays (Table 2). G. toxicus, G. caribaeus and G. pacificus were detected at trace concentrations in the WS samples whatever the site (Table 2).

In parallel, several Gambierdiscus clonal cultures were also established from cells collected on window screens. Among the 17 cultured strains originating from Nuku Hiva, G. carpenteri was the most prevalent species since 13 strains belonged to G. carpenteri, 3 strains belonged to G. pacificus and only 1 strain belonged to G. polynesiensis (Table 3). None of these strains belonged to G. caribaeus or G. toxicus. Surprisingly, the G. polynesiensis strain was established successfully from material originating from Taiohae Bay where it was present at low densities on WS (10\%) (Table 2). In the same way, three strains of G. pacificus were established from samples collected from Taiohae and Taipivai Bays where G. pacificus was also detected at low densities $\left(<1\right.$ cell $\left./ 150 \mathrm{~cm}^{-2}\right)$. Conversely, G. polynesiensis was 
not successfully isolated in culture from Anaho Bay WS samples, although it was the most prevalent species in this area ( $82 \%$ ) (Table 2). These observations indicate that the culturing approach may give a highly biased representation of the community species composition.

Table 3. Identification to the species level of the in vitro culture strains of Gambierdiscus spp. isolated from window-screen samples deployed in Nuku Hiva Island.

\begin{tabular}{ccccc}
\hline \multirow{2}{*}{ Site } & \multicolumn{4}{c}{ Gambierdiscus Species } \\
\cline { 2 - 5 } & $\boldsymbol{n}^{\mathbf{1}}$ & G. polynesiensis & G. carpenteri & G. pacificus \\
\hline Anaho & 11 & 0 & 11 & 0 \\
Taipivai & 2 & 0 & 1 & 1 \\
Taiohae & 4 & 1 & 1 & 2 \\
\hline & ${ }^{1} n$ n number of cultured strains established in the laboratory.
\end{tabular}

\subsection{Toxicity Results Using $C B A-N 2 a$}

\subsubsection{Calibration of CBA-N2a}

Calibration of CBA-N2a was performed using P-CTX-3C, P-CTX-3B, P-CTX-4A and P-CTX-4B standards obtained from the Louis Malardé Institute's bank of standards. Under $\mathrm{OV}^{+}$conditions (cells treated with ouabain and veratridine mixture), neuro-2a cells typically displayed a sigmoid dose-response curve in the presence of P-CTXs, whereas no cytotoxicity was observed under $\mathrm{OV}^{-}$ conditions (untreated cells without ouabain and veratridine added) (Figure 1). Concentrations effective at 50\% (EC50 values) obtained for P-CTX-3C, P-CTX-3B, P-CTX-4A and P-CTX-4B were $1.44 \pm 0.70$ $(n=9), 5.20 \pm 1.34(n=7), 12.95 \pm 1.89(n=8)$ and $12.08 \pm 4.13(n=6) \mathrm{fg} / \mu \mathrm{L}$, respectively. The most potent toxin was P-CTX-3C, followed by P-CTX-3B, with P-CTX-4A and P-CTX-4B showing similar potency (Figure 1). The CBA-N2a was also calibrated with P-CTX-1B $\left(E_{50}=1.94 \pm 0.41 \mathrm{fg} / \mu \mathrm{L}\right.$, $n=5)$ for further comparison of the toxin content in T. niloticus with both the U.S. Food and Drug Administration (US-FDA) and the European Food Safety Authority (EFSA) advisory levels (0.01 ng equiv./g of flesh) [24,25].

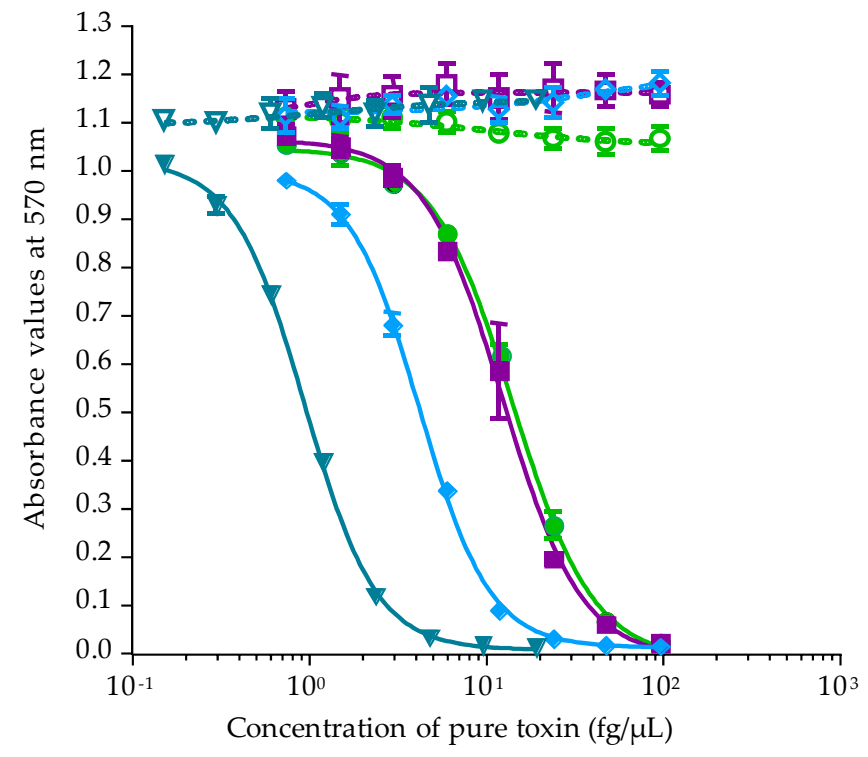

Figure 1. Dose-response curves of Neuro-2a cells in $\mathrm{OV}^{-}$(open symbols) and $\mathrm{OV}^{+}$(solid symbols) conditions, when exposed to increasing concentrations of P-CTX-3C $(\nabla / \nabla)$, P-CTX-3B $(\diamond / \diamond)$, P-CTX-4A ( $\square / \square)$ and P-CTX-4B ( / $)$ following the CBA-N2a procedure described in Section 4.4. Data represent the mean $\pm \mathrm{SD}$ of one experiment (each concentration run in triplicate). 


\subsubsection{Toxicity of Gambierdiscus In Vitro Cultures}

Among the 17 in vitro cultures tested by CBA-N2a, only G. polynesiensis strain TIO-10 originating from Taiohae was found to produce P-CTXs, as shown in Figure 2. Indeed, its liposoluble fraction showed no cytotoxicity under $\mathrm{OV}^{-}$conditions, whereas a sigmoidal dose-response curve was observed in $\mathrm{OV}^{+}$conditions, a response typical of CTXs bioactivity. Its raw EC 50 was $1.92 \pm 0.22 \mathrm{pg} / \mu \mathrm{L}$ of dry extract $(n=2)$ corresponding to $(1.21 \pm 0.14) \times 10^{-3}$ cell equiv. $/ \mu \mathrm{L}$. The mean toxin content in G. polynesiensis TIO-10 was thus estimated to be $1.20 \pm 0.14 \mathrm{pg}$ P-CTX-3C equiv./cell.

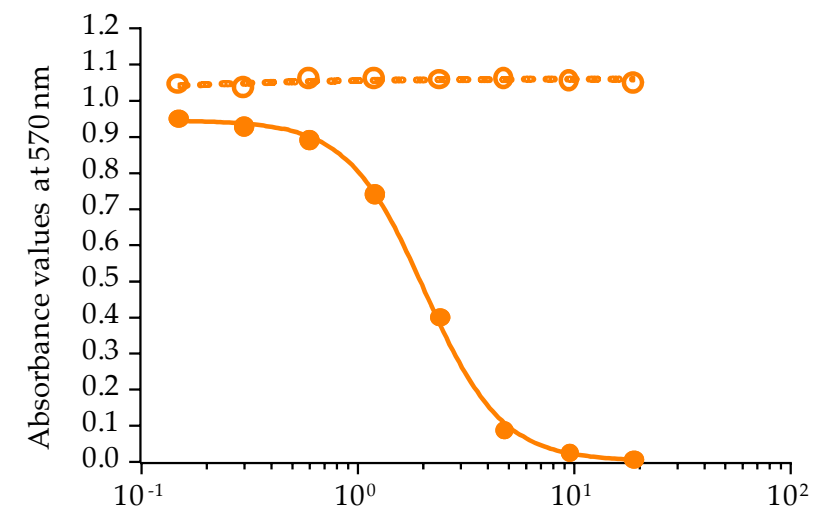

Figure 2. Dose-response curves of neuro-2a cells in $\mathrm{OV}^{-}(\bigcirc)$ and $\mathrm{OV}^{+}(\odot)$ conditions, when exposed to increasing concentrations of liposoluble fraction of G. polynesiensis strain TIO-10 isolated from Taiohae Bay. Data represent the mean $\pm \mathrm{SD}$ of one experiment (each concentration run in triplicate).

\subsubsection{Toxicity of T. niloticus Samples}

The toxicity of T. niloticus extracts obtained from field samples collected from the three study sites was investigated by examining both liposoluble fractions (LF70/30, LF90/10, LF100) and hydrosoluble fractions (HF50/50, HF70/30, HF90/10, HF100).

1. Samples from Anaho Bay

Except for HF50/50, all T. niloticus fractions corresponding to samples collected from Anaho Bay in July 2014 displayed a negative response in $\mathrm{OV}^{-}$conditions and a typical sigmoidal dose-response curve in $\mathrm{OV}^{+}$conditions, a result typical of the mode of action of CTXs (Figure 3a,b).

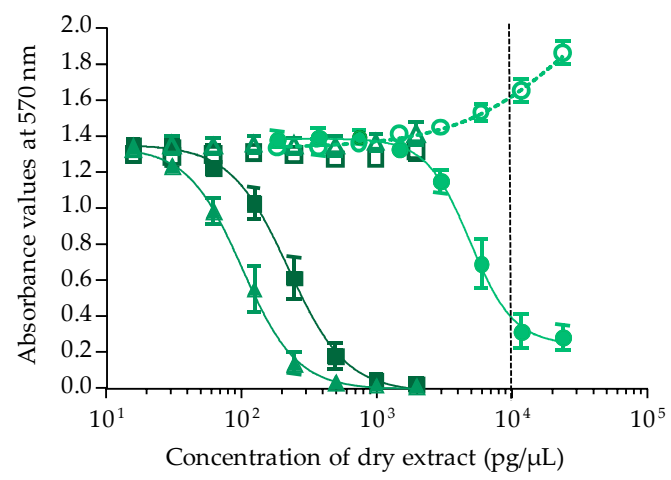

(a)

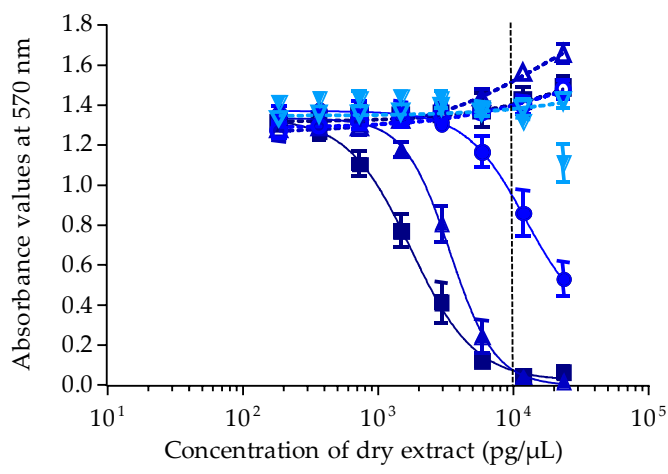

(b)

Figure 3. Dose-response curves of neuro-2a cells in $\mathrm{OV}^{-}$(open symbols) and $\mathrm{OV}^{+}$(solid symbols) conditions, when exposed to increasing concentrations of T. niloticus fractions (Anaho Bay July 2014). (a) Liposoluble fractions LF70/30 ( / /), LF90/10 ( $\triangle / \Delta)$ and LF100 ( $\square / \square)$; (b) hydrosoluble fractions $\operatorname{HF50/50}(\nabla / \nabla), \operatorname{HF70/30}(\bigcirc / \bullet), \operatorname{HF90/10}(\triangle / \Delta)$ and HF100 ( $\square / \mathbf{\square})$. Data represent the mean \pm SD of two independent experiments (each run in triplicate). The dotted vertical line corresponds to the maximum concentration of dry extract $(\mathrm{MCE}=10,000 \mathrm{pg} / \mu \mathrm{L})$ for matrix interferences. 
For all positive fractions of $T$. niloticus, raw $\mathrm{EC}_{50}$ values expressed in $\mathrm{pg} / \mu \mathrm{L}$ of dry extract were converted into $\mu \mathrm{g}$ flesh equiv./ $\mu \mathrm{L}$. For liposoluble fractions, the $\mathrm{EC}_{50}$ values were $46.86 \pm 16.23$ $(n=2), 0.23 \pm 0.07(n=4)$ and $0.35 \pm 0.07(n=4) \mu \mathrm{g}$ flesh equiv. $\mu \mathrm{L}$ for LF70/30, LF90/10 and LF100, respectively, with $\mathrm{L} 90 / 10$ being the most potent of liposoluble fractions (Figure 3a). For hydrosoluble fractions, the $\mathrm{EC}_{50}$ estimated for HF90/10 and H100 were $20.36 \pm 1.79(n=3)$ and $15.40 \pm 4.34$ $(n=3) \mu \mathrm{g}$ flesh equiv./ $\mu \mathrm{L}$, respectively, with HF100 being the most potent of hydrosoluble fractions (Figure $3 b$ ). Conversely, HF50/50 was found nontoxic, while the activity detected in HF70/30 was likely due to the matrix effect $\left(\mathrm{EC}_{50}=13,000>\mathrm{MCE}\right)$. Regarding T. niloticus collected in December 2014, typical P-CTXs' responses were observed in only three fractions, i.e., LF90/10, LF100 and HF90/10 with corresponding $\mathrm{EC}_{50}$ values of $0.91 \pm 0.06(n=3), 2.82 \pm 0.29(n=3)$ and $23.04 \pm 2.80(n=3) \mu \mathrm{g}$ flesh equiv./ $\mu \mathrm{L}$, respectively (Figure 4a). As for T. niloticus collected in November 2016, only fraction LF90/10 displayed a response typical of CTXs activity, with an $\mathrm{EC}_{50}$ value of $2.29 \pm 0.22(n=3) \mu \mathrm{g}$ flesh equiv./ $\mu \mathrm{L}$ (Figure $4 \mathrm{~b}$ ). For all T. niloticus samples, LF90/10 was the most potent fraction (Figure 4).

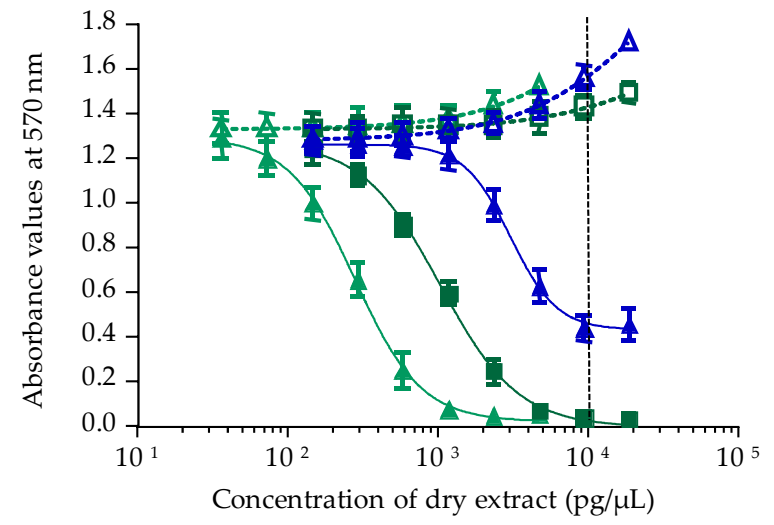

(a)

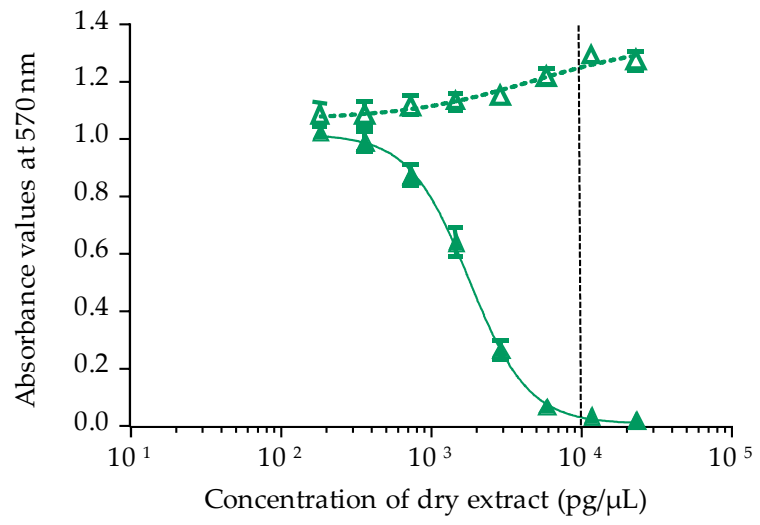

(b)

Figure 4. Dose-response curves of neuro-2a cells in $\mathrm{OV}^{-}$(open symbols) and $\mathrm{OV}^{+}$(solid symbols) conditions, when exposed to increasing concentrations of T. niloticus extracts from Anaho Bay. (a) Samples collected in December 2014; (b) samples collected in November 2016. Liposoluble fractions are represented as follows: LF90/10 ( $\triangle / \Delta)$ and LF100 $(\square / \square)$ and hydrosoluble fractions HF90/10 $(\triangle / \Delta)$. Data represent the mean $\pm \mathrm{SD}$ of three independent experiments (each run in triplicate). The dotted vertical line corresponds to the maximum concentration of dry extract $(\mathrm{MCE}=10,000 \mathrm{pg} / \mu \mathrm{L}$ ) for matrix interferences.

The toxin content in fractions positive in CBA-N2a was further estimated (Table 4). Regardless of the sampling date, $\approx 97 \%$ of the total toxin content was found in the liposoluble fractions, primarily in LF90/10 followed by LF100, vs. only $3 \%$ in the hydrosoluble fractions (Table 4). Additionally, while CTXs were detected in almost all fractions collected in July 2014, only three and one fractions were found to contain residual ciguatoxicity six months (December 2014) and 28 months (November 2016) after the report of the poisoning incident, respectively.

The total toxin contents in T. niloticus samples collected in Anaho Bay were estimated at $11.47 \pm 3.91,2.16 \pm 0.17$ and $0.67 \pm 0.06 \mathrm{ng}$ P-CTX-3C equiv./g of flesh in July 2014, December 2014 and November 2016, respectively. The total toxin content showed a five-fold decrease between July and December 2014 and a 4.5-fold decrease between December 2014 and November 2016. Overall, the toxicity in T. niloticus of Anaho Bay decreased 25-fold from July 2014 until November 2016.

The conversion of the CBA-N2a results in P-CTX-1B equivalents gave the following values of $15.45 \pm 5.26,2.91 \pm 0.23$ and $0.90 \pm 0.08 \mathrm{ng}$ P-CTX-1B equiv./g of flesh respectively, for July 2014, December 2014 and November 2016, which largely exceed the advisory levels of $0.01 \mathrm{ng}$ P-CTX-1B equiv./g of flesh recommended by both the US-FDA and the EFSA $[24,25]$. These values expressed in P-CTX-1B equivalents are slightly higher than the values expressed in P-CTX-3C equivalents as 
the $\mathrm{EC}_{50}$ of these two toxins were $1.44 \pm 0.70$ and $=1.94 \pm 0.41 \mathrm{fg} / \mu \mathrm{L}$, respectively, for P-CTX-3C and $\mathrm{P}-\mathrm{CTX}-1 \mathrm{~B}$, in our CBA-N2a experiments.

Table 4. Toxin content estimates in T. niloticus samples collected from Anaho Bay in July 2014, December 2014 and November 2016. Toxicity data were obtained using CBA-N2a. Each value represents the mean $\pm \mathrm{SD}$ ( $n=2-4$ experiments).

\begin{tabular}{cccc}
\hline \multirow{2}{*}{ Fractions } & \multicolumn{3}{c}{ Toxin Content $^{\mathbf{1}}$} \\
\cline { 2 - 4 } & July 2014 & December 2014 & November 2016 \\
\hline LF70/30 & $0.03 \pm 0.01$ & ND $^{2}$ & ND \\
LF90/10 & $6.63 \pm 1.95$ & $1.59 \pm 0.11$ & $0.67 \pm 0.06$ \\
LF100 & $4.63 \pm 1.63$ & $0.51 \pm 0.05$ & ND \\
HF50/50 & $\mathrm{ND}$ & $\mathrm{ND}$ & $\mathrm{ND}$ \\
HF70/30 & $\mathrm{ND}$ & $\mathrm{ND}$ & $\mathrm{ND}$ \\
HF90/10 & $0.07 \pm 0.01$ & $0.06 \pm 0.01$ & $\mathrm{ND}$ \\
HF100 & $0.10 \pm 0.03$ & $\mathrm{ND}$ & $\mathrm{ND}$ \\
Total toxin content & $11.47 \pm 3.91$ & $2.16 \pm 0.17$ & $0.67 \pm 0.06$ \\
\hline
\end{tabular}

${ }^{1}$ Results expressed in ng P-CTX-3C equiv./g of flesh. ${ }^{2}$ ND: not detectable.

\section{Samples from Taiohae and Taipivai Bays}

All liposoluble and hydrosoluble fractions obtained from T. niloticus collected from Taiohae (December 2014 and November 2016) and Taipivai (December 2014) were negative in $\mathrm{OV}^{-}$and $\mathrm{OV}^{+}$ conditions (data not shown). These findings confirm that the ciguatoxicity observed in T. niloticus sampled from Anaho Bay is not the result of matrix interferences.

In contrast, T. niloticus collected from Taipivai in November 2016 displayed sigmoid dose response curves in both $\mathrm{OV}^{-}$and $\mathrm{OV}^{+}$conditions for three fractions, atypical of CTXs activity (Figure 5).

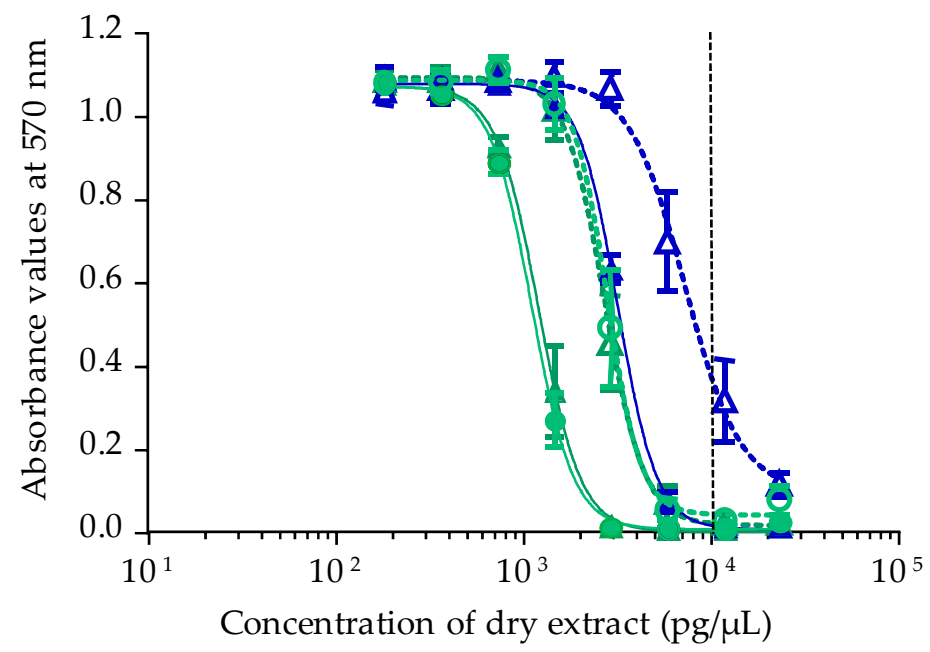

Figure 5. Dose-response curves of Neuro-2a cells in $\mathrm{OV}^{-}$(open symbols) and $\mathrm{OV}^{+}$(solid symbols) conditions, when exposed to increasing concentrations of T. niloticus fractions originated from Taipivai (November 2016) LF70/30 $(\odot / \odot), \operatorname{LF90/10~}(\Delta / \Delta)$ and HF90/10 $(\Delta / \Delta)$ following the CBA-N2a procedure described in Section 4.4. Data represent the mean $\pm \mathrm{SD}$ of two independent experiments (each run in triplicate). The dotted vertical line corresponds to the maximum concentration of dry extract $(\mathrm{MCE}=10,000 \mathrm{pg} / \mu \mathrm{L})$ for matrix interferences.

For the three positive fractions, the corresponding $\mathrm{EC}_{50}$ values in $\mathrm{OV}^{-} / \mathrm{OV}^{+}$conditions were: i.e., LF70/30: $20.49 \pm 0.57$ and $8.57 \pm 0.09 \mu \mathrm{g} / \mu \mathrm{L}$, respectively; LF90/10: $4.96 \pm 0.15$ and $2.22 \pm 0.19 \mu \mathrm{g} / \mu \mathrm{L}$, respectively; and HF90/10: ND and $78.23 \pm 3.43 \mu \mathrm{g} / \mu \mathrm{L}$, respectively. For all three fractions, $\mathrm{EC}_{50}$ 
values in $\mathrm{OV}^{+}$conditions were higher than those obtained in $\mathrm{OV}^{-}$conditions. LF70/30 and LF90/10 fractions had the same potency and were more potent than HF90/10. As these results were not typical of the P-CTX mode of action, no toxin content has been estimated.

\subsection{Toxin Profiles in Tectus niloticus Toxic Fractions Using LC-MS/MS}

\subsubsection{Detection of Pacific Ciguatoxins in T. niloticus from Nuku Hiva}

LC-MS/MS analyses confirmed the presence of P-CTXs in T. niloticus collected from Anaho Bay in July 2014, December 2014 and November 2016 (Figure 6A-D).
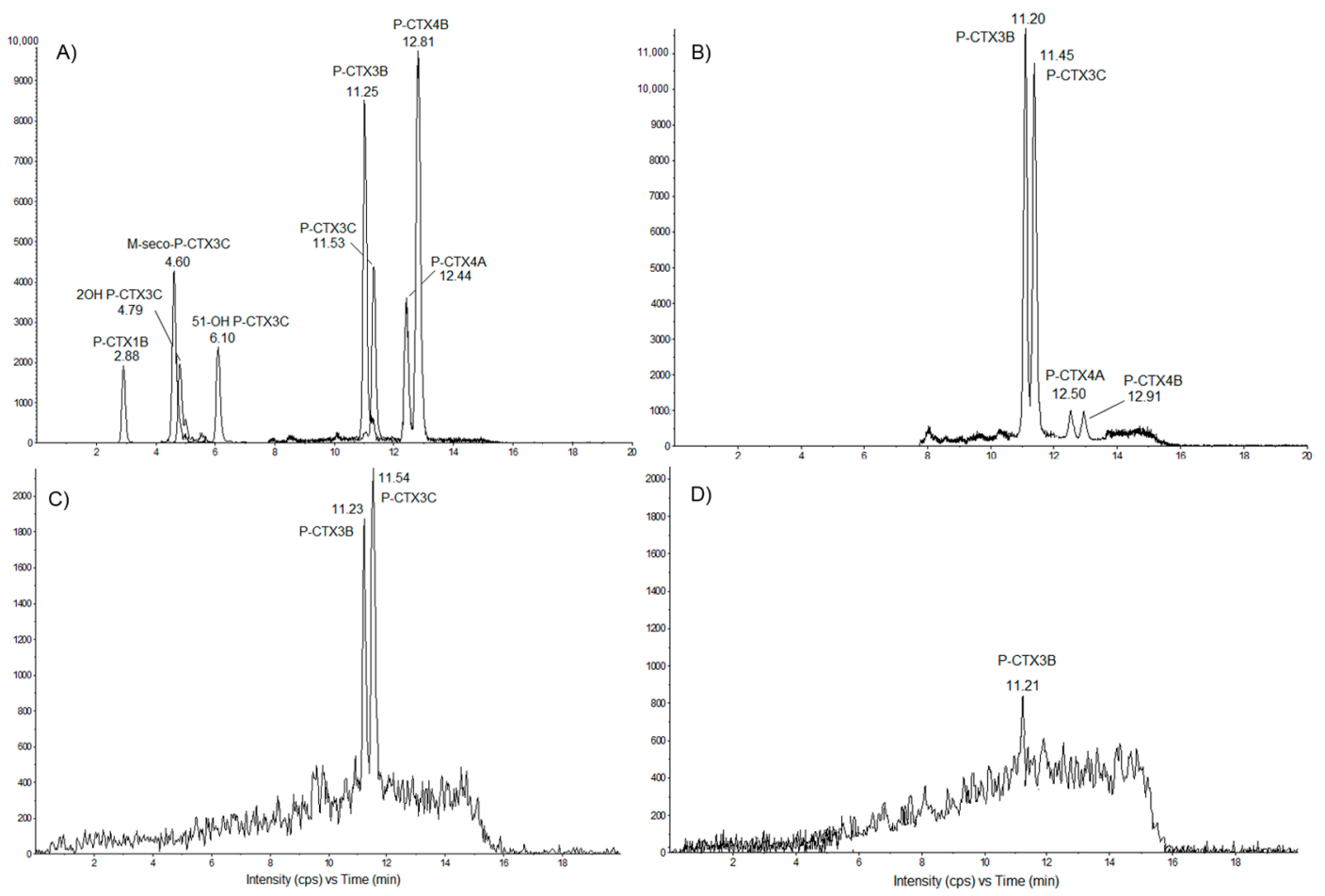

Figure 6. LC-MS/MS chromatograms obtained for (A) a mix of P-CTX standards (provided by Institut Louis Malardé) and Solid Phase Extraction-purified extracts of Tectus niloticus collected from Anaho Bay in (B) July 2014, (C) December 2014 and (D) November 2016. Chromatograms were acquired following the procedure described in Section 4.5 , in positive multi-reaction monitoring (MRM) mode.

In T. niloticus collected in July 2014 (Figure 6B), P-CTX-3B, P-CTX-3C, P-CTX-4A and P-CTX-4B were formally identified in comparison with standards (Figure 6A). For T. niloticus sampled in December 2014, P-CTX-3B and P-CTX-3C were formally identified in comparison with standards, whereas P-CTX-4A and P-CTX-4B were not detected (Figure 6C). As for T. niloticus collected in November 2016 (Figure 6D), only P-CTX-3B was formally identified in comparison with standards, whereas P-CTX-3C, P-CTX-4A and P-CTX-4B were not detected (Figure 6D).

Conversely, no CTXs were detected in T. niloticus from Taipivai Bay collected during the same periods.

The toxin profile of the T. niloticus extracts was determined and quantified using a calibration range of P-CTX-3C (Wako supplier) (Table 5). In the first extract (FE) obtained from T. niloticus collected in July 2014, P-CTX-3B was the most prevalent toxin congener $(65 \%)$ with a toxin content twice as much as for P-CTX-3C (35\%), while the more purified Solid Phase Extraction (SPE Si) extract displayed an even more diverse toxin profile including P-CTX-3B (65\%), P-CTX-3C (28\%) and P-CTX-4A/B ( $4 \%$ each), without significant loss $(>90 \%)$. 
Table 5. Estimation of the relative concentrations of P-CTXs congeners in T. niloticus collected in Anaho Bay using LC-MS/MS.

\begin{tabular}{ccccccc}
\hline Date & Fractions & P-CTX-3C & P-CTX-3B & P-CTX-4A & P-CTX-4B & Total \\
\hline \multirow{2}{*}{ July 2014 } & First Extract FE & 8.1 & 14.81 & $<$ LD $^{1}$ & $<$ LD & 23 \\
& SPE Si Extract & 5.8 & 13.0 & 0.9 & 0.8 & 21 \\
\hline December 2014 & SPE Si Extract & 3.57 & 2.2 & $<$ LD & $<$ LD & 5.8 \\
November 2016 & SPE Si Extract & <LD & 1.16 & $<$ LD & $<$ LD & 1.16 \\
\hline
\end{tabular}

${ }^{1}$ Results expressed in ng P-CTX-3C equiv./g of flesh with a detection limit of $0.05 \mathrm{ng}$ P-CTX-3C equiv./g of flesh.

The toxin profile assessed for T. niloticus extracts collected in December 2014 consisted of P-CTX-3C as the most prevalent toxin (61\%), followed by P-CTX-3B (38\%), whereas in the November 2016 samples, only P-CTX-3B accounted for the residual toxicity monitored in T. niloticus.

Based on the data presented in Table 5, the total toxin contents in T. niloticus samples were estimated at 23/21, 5.8 and $1.16 \mathrm{ng}$ P-CTX-3C equiv./g of flesh in July 2014, December 2014 and November 2016, respectively (Table 5). These values indicate a 3.7-fold decrease in toxicity between July and December 2014, a 5-fold decrease between December 2014 and November 2016 or an overall 19-fold decrease from July 2014 until November 2016.

When converted into P-CTX-1B equivalents, the following toxin contents were obtained: 2.3/2.1, 0.58 and $0.12 \mathrm{ng}$ P-CTX-1B equiv./g of flesh in July 2014, December 2014 and November 2016 samples, respectively, which again largely exceed the recommended action value of $0.01 \mathrm{ng}$ P-CTX-1B equiv./g of flesh proposed by both the U.S. FDA and EFSA [24,25].

Despite the fact that toxin contents estimated from CBA-N2a and LC-MS/MS analysis appeared different by a factor of almost two, our findings indicate that: (i) the general trend observed in the decrease of T. niloticus toxicity over time from Anaho Bay remains consistent between these two analytical methods; and (ii) T. niloticus were able to accumulate CTXs in their tissues at levels well above the threshold indicated for human poisoning.

\subsubsection{Screening of T. niloticus Samples for Other Marine Toxins}

As CBA-N2a results of T. niloticus samples from Taipivai in November 2016 were not characteristic of the presence of P-CTXs, a multi-toxin screening was conducted on T. niloticus samples from both Anaho (July 2014, December 2014 and November 2016) and Taipivai (November 2016).

No NSP toxins (brevetoxin group), DSP toxins as okadaic acid (OA), dinophysistoxins (DTXs), azaspiracids (AZAs) and yessotoxins (YTXs), no pectenotoxins (PTXs), as well as FATs comprising gymnodimines (GYMs), spirolides (SPXs) and pinnatoxins (PnTXs) were found in T. niloticus from Anaho Bay.

Only T. niloticus samples from Taipivai in November 2016 presented two peaks with an $m / z$ of the parent ion corresponding to that of AZA2, albeit with different retention times and spectral signatures (Figure 7).

Fragmentation of the parent ion $m / z 856.6$ was conducted using positive EPI mode on the API 4000Qtrap to verify if these intense peaks belong to the azaspiracid family. As previously described, azaspiracid analogs show characteristic fragmentation patterns in MS/MS analysis [26].

The MS/MS spectra obtained for the suspected peaks were compared to the fragmentation pattern of AZA2 (Figure 7), but the presence of known AZA analogs (AZA1-AZA32) could not be confirmed. 


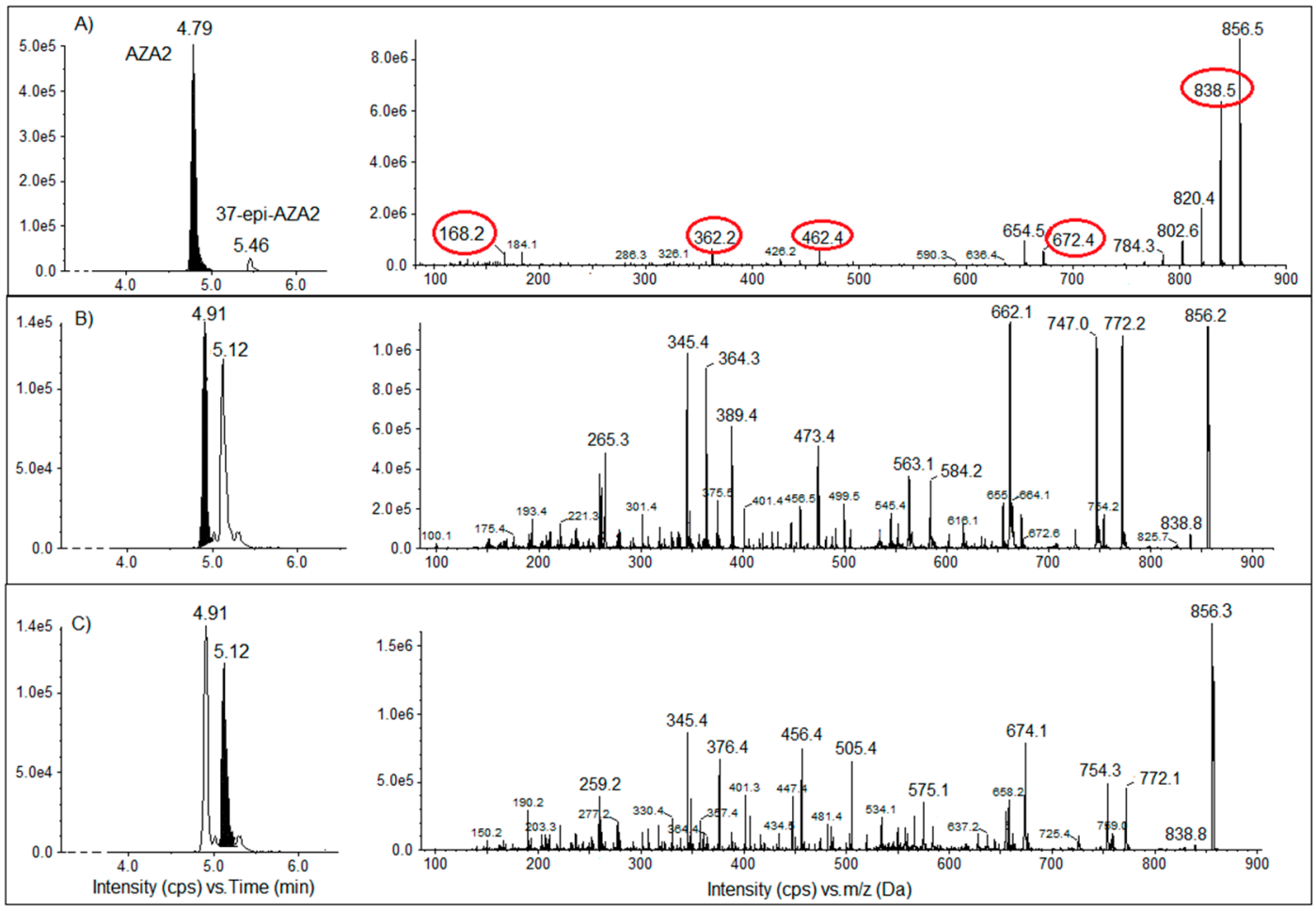

Figure 7. Chromatographic peaks of the $m / z 856.6$ ion with the corresponding MS/MS spectra of (A) AZA2 (AZA, azaspiracid) from National Research Council Canada (NRC) at 4.79 min; (B,C) Tectus niloticus extract from Taipivai collected in November 2016, at respectively, $4.91 \mathrm{~min}$ and $5.12 \mathrm{~min}$. MS/MS spectra of the $m / z 856.6$ were obtained using positive enhanced product ion (EPI) mode with a collision energy (CE) of $50 \mathrm{eV}$ and a collision energy spray (CES) of $20 \mathrm{eV}$. Specific fragment ions of the azaspiracid group are indicated in red.

\section{Discussion}

A food poisoning outbreak involving nine tourists following the consumption of the gastropod Tectus niloticus was reported from Anaho Bay, Nuku Hiva Island (Marquesas archipelago, French Polynesia) in June 2014 [15,16]. All patients exhibited clinical symptoms typical of CFP [15]. As this poisoning incident involved an unusual vector of CFP, a toxicological survey of T. niloticus toxicity harvested from three distinct fishing sites in Nuku Hiva Island was conducted during a two-year period using both CBA-N2a and LC-MS/MS analysis.

CBA-N2a and LC-MS/MS results revealed the presence of high levels of P-CTXs only in T. niloticus specimens collected from Anaho Bay, in the same area where trochus specimens involved in the June 2014 mass-poisoning incident were harvested. Of note, the total toxin content in T. niloticus specimens on three distinct occasions, from July 2014 until November 2016, was found to be consistently above the safety limit recommended for human consumption, even 28 months after the poisoning outbreak occurred in Anaho Bay. Such findings suggest that T. niloticus is able to naturally bioaccumulate P-CTXs in its tissues and, hence, likely provides a potential bioaccumulation pathway for ciguatera toxins in marine food webs. Other marine gastropods in the Tegulidae and Trochidae families are known to bioaccumulate PSP toxins, such as Tectus nilotica pyramida and Tectus pyramis in Japan or Tectus fenestratus and Trochus hanleyanus endemic to the North-West Australian coast [27-30]. Indeed, trochus shells are found to graze on turf algae and biofilms growing on rocky and coral substrates $[6,7]$. Both field and laboratory feeding studies have established that T. niloticus feed on macroalgae belonging to Chlorophyta (Ulvaceae, Caulerpaceae) and Rhodophyta (Gracilariaceae, Solieriaceae), as well as diatoms (Bacillariaceae, Chaetocerotaceae, Naviculaceae), and other microalgae (Isochrysidaceae, Chlorodendraceae, Eustigmatophyceae) or suspended material mixed with sand and detritus [6]. These 
observations strongly suggest that T. niloticus feeding on macroalgae colonized by toxic Gambierdiscus cells are likely to concentrate algal ciguatoxins.

In the present study, low densities of Gambierdiscus were consistently observed on macroalgal samples collected from the three study sites in November 2016. However, a previous field-survey conducted in Nuku Hiva Island showed that several species of macroalgae such as Amphiroa fragilissima, Chlorodesmis fastigiata, Halimeda distorta and Chnoospora minima can harbor high densities of Gambierdiscus cells, reaching 20,000 cells/g algae, most notably in Anaho Bay [31]. Concurrently, cell densities monitored on window screens deployed in Anaho, Taipivai and Taiohae Bays, by means of qPCR techniques, confirmed that Gambierdiscus populations are present in these three sites of Nuku Hiva Island. Estimation of the relative species distribution among Anaho Bay Gambierdiscus communities indicated that G. polynesiensis was the predominant species in this toxic area. G. polynesiensis is known as one of the most toxic species of Gambierdiscus described to date [32]. The toxin profile of two Polynesian strains of this species has been well documented by Chinain et al., 2010 [17], and includes P-CTX-3C, -3B, -4A, -4B and M-seco-CTX-3C as the major CTXs congeners produced by G. polynesiensis in culture. Since LC-MS/MS analyses showed that at least four of these P-CTXs analogs were present in T. niloticus toxic samples, it can be concluded that G. polynesiensis is a likely source of the CTX analogs detected in T. niloticus from Anaho Bay. Interestingly, a recent field survey conducted in Anaho Bay by means of solid phase adsorption toxin tracking (SPATT) technology also confirmed the presence of P-CTX-3B and -3C in the environment [33]. Taken together, all these observations confirm the high ciguatera risk status that characterizes Anaho Bay, as also evidenced by the epidemiological data available for Nuku Hiva Island (incidence rates of CFP varying from 37-101/10,000 inhabitants between 2012 and 2016, www.ciguatera-online.com).

Conversely, in Taiohae and Taipivai Bays, the dominant species in the benthic communities recovered from window screens was G. carpenteri, while G. pacificus was detected only at trace concentrations in WS samples in all sites. Contrary to G. polynesiensis, G. carpenteri and G. pacificus are not known to produce significant amounts of CTX nor maitotoxins (MTXs) [17,32,34-37], consistent with the fact that no P-CTXs were detected in T. niloticus samples collected in November 2016 from these two study sites. However, the presence of a highly toxic strain of G. polynesiensis TIO-10 among the clonal cultures established in the laboratory from cell isolates from Taiohae Bay suggests that potential health hazards may be associated with the consumption of trochus harvested in this area. This emphasizes the need to keep this site under surveillance, along with the Anaho study site.

There are several possible explanations for the occurrence of the toxic algae in Anaho Bay. CFP events are triggered by both environmental and biological factors. Chinain et al., 1999 [38], have shown the existence of a seasonal trend in Gambierdiscus proliferation in French Polynesia, with maximum densities occurring during the hot season. CFP risk is also significantly increased in highly degraded coral reef ecosystems [18,20,39], which was the case in Anaho Bay (Chinain, personal communication). While anthropogenic discharges are unlikely in this uninhabited and difficult to access area, the high hydrodynamic conditions that prevail in this area throughout the hot season may partly explain the degraded status of this site.

According to Litaker et al., 2010 [40], CFP events are driven more by inherent differences in species toxicity than by environmental modulation. Chinain et al., 1999 [38], have also speculated that the toxicity in a given area is mainly dependent on the clonal nature of cells that coexist within local Gambierdiscus populations. In other words, the high proportion of G. polynesiensis cells in Anaho Bay may account for the high CFP risk in this area. Recent studies have shown that temperature, salinity and irradiance tolerance may vary greatly across multiple species of Gambierdiscus [41-44]. Such differences may in turn influence the growth and distribution of these species in a given area. Additionally, since Gambierdiscus is often found as part of a mixed assemblage of benthic dinoflagellates on macroalgal substrates, the existence of allelochemical-mediated growth stimulation or inhibition mechanisms may help explain why G. polynesiensis turned out to be the dominant species in Anaho Bay [44-46]. 
Based on LC-MS/MS analyses, four distinct P-CTX analogs were currently detected in T. niloticus tissues, namely P-CTX-3B, $-3 \mathrm{C},-4 \mathrm{~A}$ and $-4 \mathrm{~B}$, with $\mathrm{P}-\mathrm{CTX}-3 \mathrm{~B}$ as the major congener. This result is consistent with previous findings indicating that $\mathrm{P}-\mathrm{CTX}-3 \mathrm{~B}$ is also the predominant congener detected in giant clams (Tridacna maxima) experimentally fed G. polynesiensis cells [23].

In the present study, the toxicity in T. niloticus samples from Anaho Bay was monitored at different time periods corresponding to 1, 6 and 28 months after the mass-poisoning was reported. The total toxin content estimated in toxic fractions based on CBA-N2a and LC-MS/MS data showed a 19-25-fold decrease in the overall ciguatoxicity of these samples (depending on the detection test) between July 2014 and November 2016, suggesting a slow depuration rate for CTXs in these marine invertebrates. However, this finding may also be confounded by additional accumulation over the two-year period, even through low levels of Gambierdiscus. Dynamics of PSP toxins accumulation and elimination is well documented in a variety of bivalve mollusks such as mussels, scallops, oysters and clams fed toxic dinoflagellates (Alexandrium, Ostreopsis, Azadinium) [47-51]. In contrast, the processes controlling the uptake, metabolization and depuration of CTXs are still poorly addressed in marine invertebrate species prone to ciguatera [23], especially gastropods, stressing the urgent need for further investigations in this field of research, since such knowledge will greatly benefit both ciguatera risk management programs and predictive models of CTX accumulation in these organisms.

The implication of various marine invertebrates in ciguatera events is well documented in the Pacific region and, to a lesser extent, in Atlantic localities. In addition to poisoning cases involving Tridacna maxima (bivalve mollusk) or Tripneustes gratilla (echinoderms) frequently observed in French Polynesia, New Caledonia and Cook islands [19,21,22,52], toxic lobsters Panulirus penicillatus and octopus have also been reported in the Republic of Kiribati [53]. More recently, ciguatoxin congeners were also evidenced in the starfish Ophidiaster ophidianus and Marthasterias glacialis collected from the northwestern Moroccan coast [54]. In some instances where atypical ciguatera symptoms were observed (e.g., rapid onset of the clinical symptoms, unusual severity of the poisoning which necessitated the hospitalization of patients), the potential contribution of marine cyanobacteria belonging to the Oscillatoriales (e.g., Trichodesmium, Oscillatoria and Hydrocoleum) was suspected and led to the description of a new ecotoxicological phenomenon tentatively designated ciguatera shellfish poisoning (CSP) [19,52]. Further toxicological analysis revealed the production of a variety of toxic metabolites in these cyanobacteria, including ciguatoxin-like compounds, anatoxin-a and homoanatoxin-a, palytoxin and 42-hydroxy-palytoxin [19,52,55-58]. Because similar atypical symptoms were also observed in patients poisoned in Anaho Bay, a multi-toxin screening by means of LC-MS/MS targeted at paralytic shellfish poisoning toxins, diarrhetic shellfish poisoning toxins, cyclic imines (fast action toxins (FAT)) and brevetoxins is currently underway on T. niloticus samples collected in Nuku Hiva Island in November 2016. Preliminary results strongly suggest the presence of yet undescribed AZAs (azaspiracid toxins) analogs (the presence of two peaks with an $m / z$ equivalent to the peak of AZA2, but with different retention times), at least in the trochus samples from Taipivai Bay. Analyses for the presence of Azadinium spp. cells in water samples collected from this site were negative.

T. niloticus is of high value for many island communities in PICTs where it represents not only a significant source of revenue, but also a valuable nutritional resource. This study is the first to provide evidence that the consumption of trochus shell meat may represent a potential health risk in French Polynesia. Indeed, high levels of CTXs exceeding the advisory levels recommended by the European Food Safety Authority (EFSA) [24] and the Food and Drug Administration (FDA) [25] were detected in the tissues of T. niloticus collected from Anaho Bay, a long-standing ciguatera hotspot in Nuku Hiva Island. Moreover, the potential presence of other toxic compounds in these marine invertebrates points to the importance of: (i) maintaining an eco-toxicological surveillance in areas already identified to present a high risk for poisoning; (ii) document the prevalence of such poisoning events in other localities of French Polynesia; and (iii) conduct sustained educational interventions to increase public 
awareness in order to minimize the risk of seafood intoxication by ingestion of T. niloticus in both local populations and visitors.

\section{Materials and Methods}

\subsection{Study Sites}

Samples (macroalgal substrates, window screens and T. niloticus specimens) were collected from 3 distinct study sites on Nuku Hiva Island (Marquesas archipelago, French Polynesia), namely Anaho, Taipivai and Taiohae bays located in the northern, eastern and southern coasts of the Island, respectively (Figure 8). Anaho Bay has been regarded as a long-standing hotspot of ciguatera since 2004 [31].

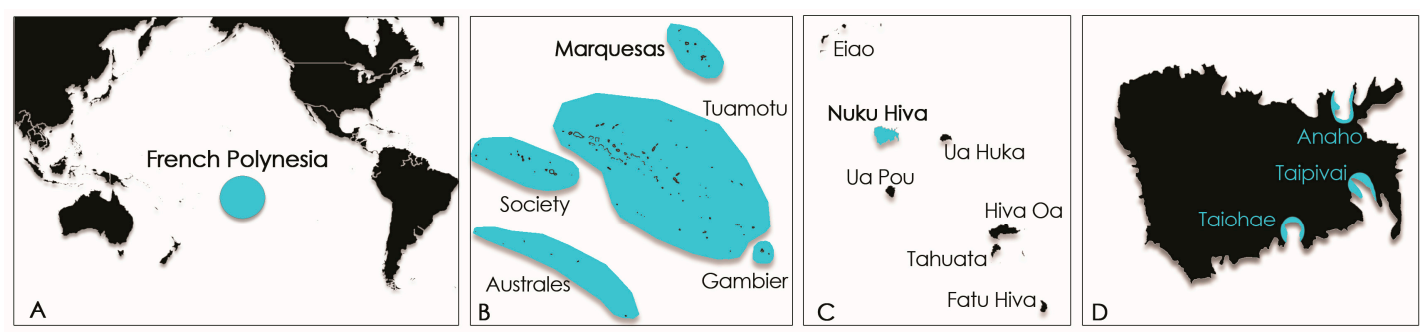

Figure 8. Maps of French Polynesia (A,B) and Nuku Hiva Island (Marquesas archipelago), (C) showing the locations of the 3 study sites and (D) areas sampled in this study.

\subsection{Biological Material and Sampling Procedures}

\subsubsection{Gambierdiscus Samples and qPCR Assays}

Wild samples of Gambierdiscus analyzed in this study from Anaho, Taipivai and Taiohae bays, using both the natural (i.e., macroalgae) and the artificial (i.e., window screens) substrate methods were collected in November 2016 [59]. Briefly, $\approx 200 \mathrm{~g}$ of turf-like and Halimeda micronesia macroalgal hosts were collected at water depths of 1-5 m and examined for the presence of Gambierdiscus cells. Macroalgal samples were sealed within plastic bags underwater and shaken and kneaded vigorously to dislodge dinoflagellate cells. The detrital suspension was then successively filtered through 125-, 40and $20-\mu \mathrm{m}$ mesh sieves and the $40-$ and $20-\mu \mathrm{m}$ fractions preserved in $50 \mathrm{~mL}$ of $5 \%$ formalin-seawater. Cell densities were assessed microscopically from $100-\mu \mathrm{L}$ aliquots of these two fractions. Values were expressed in cells/g algal wet weight and represented the mean number of cells enumerated on $n$ $(=2-8)$ sub-samples of the same host algae species [20]. The artificial substrate method used $150 \mathrm{~cm}^{2}$ window screen (WS) devices assembled and deployed in the same areas. A total of 6 WSs were deployed per areas; $100 \%$ of the WS were recovered. After $24 \mathrm{~h}$, WS were harvested with $250 \mathrm{~mL}$ of sea water and shaken to dislodge the cells from the WS. The entire volume was filtered through 10- $\mu \mathrm{m}$ polycarbonate filters that were replaced as the filters became obstructed. Then, all filters used to process individual samples were transferred into $15 \mathrm{~mL}$ tubes with $8 \mathrm{~mL}$ of sterile filtered sea water. Before removing the filters, the tubes were shaken to dislodge Gambierdiscus cells. Enumeration of cells was performed microscopically on $1 \mathrm{~mL}$ aliquots and by qPCR estimation on the remaining $7 \mathrm{~mL}$ as described below. Cell concentrations were expressed as cells $/ 150 \mathrm{~cm}^{2}$ [59].

Concurrently, 17 in vitro culture clones of Gambierdiscus spp. were also established in the laboratory from single cell isolates collected from WS samples, according to the method used by Chinain et al., 2010 [20].

Semi-quantitative, species-specific qPCR assays were used to survey the WS samples for relative cell abundance and Gambierdiscus species distribution. Each 7-mL WS aliquot was filtered onto 47-mm 8- $\mu \mathrm{m}$ polycarbonate filters, and DNA was extracted from each filter as described by Vandersea et al., 2012 [60], using the Power Soil DNA isolation Kit (Quiagen, Hilden, Germany) following the manufacturer's protocol, except that $350 \mu \mathrm{L}$ of cell lysate rather than the prescribed $450 \mu \mathrm{L}$ were 
processed. The DNA extracts were eluted from the mini columns using $50 \mu \mathrm{L}$ of elution buffer and stored at $4{ }^{\circ} \mathrm{C}$. Taxonomic identification of in vitro cultures and enumeration of wild cells collected on WS were conducted using qPCR assays described by Vandersea et al., 2012 [60], using species-specific primers for G. belizeanus, G. caribaeus, G. carpenteri, G. carolinianus, G. ruetzleri and Gambierdiscus ribotype 2. The presence and abundance of Pacific Gambierdiscus species, i.e., G. polynesiensis, G. toxicus, G. pacificus and G. australes, were assessed using species-specific qPCR primer sets (Table 6) and qPCR conditions.

Table 6. Gambierdiscus species-specific qPCR primer sets used in this study.

\begin{tabular}{|c|c|c|}
\hline Species & Name of Primers & Sequences of qPCR Primers \\
\hline \multirow[b]{2}{*}{ G. australes } & GaustF10 & 5'-ATTGCTGTGTGAATACAGGTAA-3' \\
\hline & GaustR10 & 5'-CAAGCACTGCCCACAGATAC-3' \\
\hline \multirow{2}{*}{ G. pacificus } & GpacifITSF1 & 5'-AATTCGAAACAGATGTGCATGG-3' \\
\hline & GpacifITSR1 & 5'-GCCAAAGACAGCACTGATGAC-3' \\
\hline \multirow{2}{*}{ G. polynesiensis } & PolyITSF1 & 5'-TGTGTGCACGTGTGTGTATGG-3' \\
\hline & PolyITSR1 & 5'-CGCACCACCGGCGCACAG-3' \\
\hline \multirow{2}{*}{ G. toxicus } & GtoxITSF1 & 5'-TGAGACAGACGTGCATGGTTG-3' \\
\hline & GtoxITSR1 & 5'-CCAACAGCAGCACTGATGAAT-3' \\
\hline \multirow{2}{*}{ G. belizeanus } & GbelizeF1 & 5'-TAGAGGAATTGACACAAACTTG-3' \\
\hline & GbelizeR1 & 5'-CATCAGGGTTTTCAGGTCAAA-3' \\
\hline \multirow{2}{*}{ G. caribaeus } & GcaribF3 & 5'-TGTCTTTGACTGGATGACTGT-3' \\
\hline & GcaribR8 & 5'-TGTCTCCAACATGCTGGCAC-3' \\
\hline \multirow{2}{*}{ G. carpenteri } & GcarpenteriF1 & 5'-GGTGCTGTTGTGTGACCATA-3' \\
\hline & GcarpenteriR3 & 5'-CTGGCAGTGGAAGCTGACA-3' \\
\hline \multirow{2}{*}{ G. carolinianus } & GcarolinF2 & 5'-TAAATGAGAAAGGACGCAGC-3' \\
\hline & GcarolinR5 & 5'-САССТСТСАСТTСАAАTTGG-3' \\
\hline \multirow{2}{*}{ F. ruetzleri } & GrutzITSF3 & 5'-TGGATAACACCATGGGAAGTC-3' \\
\hline & GrutzITSR4 & 5'-TTCCCAGCTTCGAGGGGAAA-3' \\
\hline \multirow{2}{*}{ Gambierdiscus ribotype 2} & RiboII-F1 & 5'-TTGGAGAGTGAATCTTGTCTT-3' \\
\hline & RiboII-R1 & 5'-CGGTATCTGGCTTTGCGTG-3' \\
\hline
\end{tabular}

PCR assays were performed using an Eppendorf Mastercycler ${ }^{\circledR}$ ep RealPlex 4 system with white Eppendorf real-time tube strips (Eppendorf North America, Inc., Westbury, New York, NY, USA) and a total reaction volume of $10.5 \mu \mathrm{L}$ per tube. Each PCR reaction mixture contained $4.5 \mu \mathrm{L}$ of 5 Prime RealMasterMix SYBR ROX $2.5 \times\left(0.05\right.$ units/ $\mu \mathrm{L}$ Taq DNA polymerase, $10 \mathrm{mM} \mathrm{Mg}\left(\mathrm{CH}_{3} \mathrm{COO}\right)_{2}$, $1.0 \mathrm{mM}$ dNTPs, 20X SYBR ${ }^{\circledR}$ Green solution) each primer at a concentration of $0.15 \mu \mathrm{M}, 4.7 \mu \mathrm{L}$ of sterile deionized water and $1 \mu \mathrm{L}$ of template DNA. Thermal cycling conditions included denaturation at $95^{\circ} \mathrm{C}$ for $2 \mathrm{~min}$ followed by 40 cycles at $95^{\circ} \mathrm{C}$ for $10 \mathrm{~s}$, annealing for $15 \mathrm{~s}$ at $60^{\circ} \mathrm{C}$ with a subsequent extension at $68^{\circ} \mathrm{C}$ for $20 \mathrm{~s}$. The fluorescence threshold was determined by the Eppendorf RealPlex 4 analytical software, and the PCR cycle during which fluorescence crossed the threshold was designated the quantification cycle (Cq). A melting curve analysis was performed following thermal cycling to check the specificity of the PCR reactions. The melting curve profile consisted of denaturation at $95{ }^{\circ} \mathrm{C}$ for $15 \mathrm{~s}$ followed by an annealing step for $15 \mathrm{~s}$ at $60^{\circ} \mathrm{C}$. The fluorescence was continuously monitored during a steady 20-min temperature ramp from $60-95^{\circ} \mathrm{C}$, which was held at $95^{\circ} \mathrm{C}$ for $15 \mathrm{~s}$. The melting curve analysis was conducted by comparing the melting temperature peak of positive control DNA to other experimental DNA samples. A limit of $\pm 0.5^{\circ} \mathrm{C}$ for melting temperature peak shift was set as the cutoff for species-specific amplifications.

To quantify Gambierdiscus cells collected using WS, the construction of qPCR amplicon standard curves was necessary. rDNA fragments for each species were PCR amplified using primers that flanked the qPCR assay target sites as described by Vandersea et al., 2012 [60]. Cell-based standard curves for 
G. polynesiensis, G. toxicus, G. pacificus, G. australes, G. caribaeus and G. carpenteri were constructed as previously described. To obtain $\mathrm{qPCR}$ cell number estimates, the ratio of extractable PCR amplicons per cell was determined. The number of extractable PCR amplicons per cell was calculated by solving the regression equations derived from the diluted PCR amplicon-based standard curves using Cq values acquired from qPCR amplification of known numbers of Gambierdiscus cells. The results of this procedure enabled species-specific quantitative cell number estimates in each WS sample that was processed.

For identification at the species level, qPCR assays using the same species-specific primer sets previously described were also conducted on the 17 Gambierdiscus clonal cultures established from Nuku Hiva Island.

\subsubsection{Tectus niloticus Samples}

Since T. niloticus is currently listed among protected marine species in French Polynesia and is thus subject to a permanent fishing ban, sampling in the frame of this study was made possible through an authorization issued by the Marine and Mining Resources Directorate (Direction des Resources Marines et Minières, DRMM) of French Polynesia. Trochus specimens were collected from Anaho Bay (Figure 8) by staff members of the Public Health Directorate of Nuku Hiva Island in July 2014 and December 2014, i.e., 1 month and 6 months, respectively, after the first report of the poisoning outbreak in Anaho. A third sampling campaign conducted by the laboratory took place in Anaho, Taipivai and Taiohae Bays (Figure 8) in November 2016, i.e., 28 months after the poisoning incident occurred. The basal diameter of the shell was measured individually for all trochus samples (Table 7), and shells were sent to the DRMM or destroyed, as it is forbidden to keep them. For samples sent by the Public Health Directorate of Nuku Hiva Island in July 2014 and December 2014, the trochus specimens were boiled in order to get the meat out. The whole flesh was weighed individually and pooled before chemical extraction (Table 7). For samples collected in November 2016, the whole fresh flesh was removed by breaking the shell, weighed individually, pooled and frozen for transport to the laboratory. Then, samples were lyophilized before chemical extraction (Table 7).

Table 7. Morphological features of Tectus niloticus samples.

\begin{tabular}{cccccc}
\hline \multirow{2}{*}{ Island } & Area & Date & $n$ & $\begin{array}{c}\text { Shell Size } \\
\text { Basal Diameter (mm) }\end{array}$ & $\begin{array}{c}\text { Whole Flesh } \\
\text { Weight (g) }\end{array}$ \\
\hline \multirow{3}{*}{ Nuku Hiva } & \multirow{2}{*}{ Anaho } & July 2014 & 13 & $117.7 \pm 7.0$ & $57.63 \pm 15.2^{2}$ \\
& & December 2014 & 10 & $65.0 \pm 8.8$ & $38.2 \pm 10.4^{2}$ \\
\cline { 2 - 6 } & \multirow{2}{*}{ Taipivai } & November 2016 & 12 & $117.0 \pm 5.0$ & $87.8 \pm 19.4^{3}$ \\
\cline { 2 - 6 } & December 2014 & 13 & $62.3 \pm 7.6$ & $36.1 \pm 8.8^{2}$ \\
& Taiohae & November 2016 & 10 & $121.0 \pm 4.6$ & $100.1 \pm 7.4^{3}$ \\
\hline
\end{tabular}

${ }^{1}$ Shell size (basal diameter in $\mathrm{mm}$ ). ${ }^{2}$ Whole flesh weight boiled (g) and ${ }^{3}$ whole fresh flesh weight (g).

\subsection{Extraction Procedures}

In Pacific Island Countries and Territories like French Polynesia, T. niloticus meat is highly esteemed, and the entire trochus is consumed with or without the viscera depending on the traditional practices of the consumers. Consequently, the whole animal was extracted following a protocol adapted from Roué et al., 2016 [23]. Briefly, each pooled T. niloticus sample was extracted twice in methanol $(\mathrm{MeOH})$ and twice in $50 \%$ aqueous $\mathrm{MeOH}$, under sonication for $4 \mathrm{~h}$. After one night at $-20{ }^{\circ} \mathrm{C}$, the crude extracts were centrifuged, and the supernatants were pooled and dried under vacuum. The resulting crude extract was further partitioned between dichloromethane $\left(\mathrm{CH}_{2} \mathrm{Cl}_{2}\right)$ and $60 \%$ aqueous $\mathrm{MeOH}$ (=hydrosoluble fraction (HF)). The resulting $\mathrm{CH}_{2} \mathrm{Cl}_{2}$ phase (liposoluble fraction (LF)) was dried under vacuum and further defatted by a second solvent partition using cyclohexane 
and $80 \%$ aqueous $\mathrm{MeOH}(=\mathrm{LF})$. The $60 \%$ aqueous $\mathrm{MeOH}$ phase (HF) and $80 \%$ aqueous $\mathrm{MeOH}$ phase (LF) were then evaporated and further purified on $\mathrm{C}_{18}$ Sep-Pak cartridges (Waters ${ }^{\circledR}$, Saint-Quentin, France). For HF, the columns were pre-conditioned with $30 \%$ aqueous $\mathrm{MeOH}$ before loading extracts, washed with $30 \%$ aqueous methanol and then eluted successively with $50 \%, 70 \%$ and $90 \%$ aqueous methanol and pure methanol, resulting in 4 distinct hydrosoluble fractions, i.e., HF50/50, HF70/30, HF90/10 and HF100, respectively. For LF, the columns were pre-conditioned with $70 \%$ aqueous $\mathrm{MeOH}$ before loading extracts, washed with $70 \%$ aqueous methanol and eluted successively with $90 \%$ aqueous methanol and pure methanol, leading to 3 distinct liposoluble fractions, i.e., LF70/30, LF90/10 and LF100. All these fractions were then dried in a SpeedVac concentrator, weighted and stored at $+4{ }^{\circ} \mathrm{C}$ until tested for their toxicity.

For Gambierdiscus spp. culture samples, only the dichloromethane phase in which lipid-soluble toxins such as CTXs are recovered was kept, dried and stored until tested for its toxicity, as described by Chinain et al., 2010 [20].

\subsection{Cell-Based Assay Using Neuroblastoma Cells}

Gambierdiscus spp. and T. niloticus extracts were analyzed for their toxicity using the neuroblastoma cell-based assay (CBA-N2a), a test designed to detect the presence of toxins acting on voltage-gated sodium channels (VGSCs) such as brevetoxins and CTXs, which are both VGSCs activators [61].

The procedure for CBA-N2a follows the method previously described by Roué et al., 2016 [23]. Briefly, a density of 45,000 neuroblastoma (neuro-2a) cells $/ 200 \mu \mathrm{L} /$ well in $5 \%$ fetal bovine serum RPMI-1640 supplemented medium was seeded in a 96-well microtiter plate. After 20-24 h of growth at $37{ }^{\circ} \mathrm{C}$, in a humidified $5 \% \mathrm{CO}_{2}$ atmosphere, all wells reached $100 \%$ confluence. Then, the medium was replaced by $200 \mu \mathrm{L}$ of fetal bovine serum (FBS) 2.5\% RPMI-1640 for half of the wells and $200 \mu \mathrm{L}$ of the same medium containing an ouabain-veratridine solution (OV) at a concentration of $100 / 10 \mu \mathrm{M}$ for the other half of the wells.

Untreated cells without ouabain and veratridine added ( $\mathrm{OV}^{-}$conditions) or treated cells with ouabain and veratridine mixture $\left(\mathrm{OV}^{+}\right.$conditions) were first exposed to 4 P-CTXs standards: using a serial dilution 1:2 of eight concentrations ranging from $0.74-95.24 \mathrm{fg} / \mu \mathrm{L}$ for P-CTX-4A, P-CTX-4B, and P-CTX-3B and 0.15-19.05 fg/ $\mu \mathrm{L}$ for P-CTX-3C.

The maximum concentration of dry extract (MCE) that does not induce unspecific mortalities in neuro-2a cells was established at $10,000 \mathrm{pg} / \mu \mathrm{L}$ for both Gambierdiscus and trochus matrices. All T. niloticus fractions were tested in CBA-N2a using a serial dilution 1:2 of eight concentrations ranging from 37-9524 pg/ $\mu \mathrm{L}$ of dry extract for most of the fractions, except for LF90 and LF100, which were tested at concentrations ranging from $12-1587 \mathrm{pg} / \mu \mathrm{L}$ of dry extract. For Gambierdiscus spp. cultures, extracts were first tested at a single concentration of $9524 \mathrm{pg} / \mu \mathrm{L}$, and if toxic, a full doseresponse curve was generated by testing eight distinct concentrations ranging from $0.15-19.05 \mathrm{pg} / \mu \mathrm{L}$ of dry extract. Each concentration was tested in $\mathrm{OV}^{-}$and $\mathrm{OV}^{+}$conditions, in triplicate per plate, in two to four independent experiments.

Following another 20-22-h incubation period, cell viability was assessed using the MTT assay. The incubation medium was removed, and $60 \mu \mathrm{L}$ of RPMI-1640 medium containing $0.8 \mathrm{mg} / \mathrm{mL}$ of 3-(4,5-dimethylthiazol-2-yl)-2,5-diphenyl tetrazolium bromide (MTT) were added to each well. The plates were incubated for $45 \mathrm{~min}$ at $37^{\circ} \mathrm{C}$. Finally, the MTT was discarded, and $100 \mu \mathrm{L}$ of dimethyl sulfoxide (DMSO) were added to each well to dissolve the formazan.

The absorbance was measured at $570 \mathrm{~nm}$ using a plate reader (iMark Microplate Absorbance Reader, BioRad, Marnes la Coquette, France). For all experiments, absorbance values of $\mathrm{OV}^{-}$and $\mathrm{OV}^{+}$control wells were around 1 corresponding to $100 \%$ viability. Absorbance data were fitted to a sigmoidal dose-response curve (variable slope) based on the four-parameter logistic model (4PL) allowing the calculation of $\mathrm{EC}_{50}$ values using Prism v6.0.7 software (GraphPad, San Diego, CA, USA). Since raw results for all extracts were obtained in $\mathrm{pg} / \mu \mathrm{L}$ of dry extract, the $\mathrm{EC}_{50}$ values for 
T. niloticus and Gambierdiscus samples were further expressed in $\mu$ g flesh equiv./ $\mu \mathrm{L}$ and in cells equiv./ $\mu \mathrm{L}$, respectively.

The toxin content $(\mathrm{T})$ in the extracts was estimated using the following formula $\mathrm{T}=(\mathrm{P}-\mathrm{CTX}-3 \mathrm{C}$ $\mathrm{EC}_{50}$ / sample $\mathrm{EC}_{50}$ ) and was expressed in ng P-CTX-3C equiv./g wet weight of flesh for T. niloticus and in pg P-CTX-3C equiv./cell for Gambierdiscus samples. The limit of detection (LOD) was estimated according to the method of Caillaud et al., 2012 [62], and Roué et al., 2016 [23], and was $0.17 \mathrm{fg}$ P-CTX-3C equiv./cell and $0.02 \mathrm{ng}$ P-CTX-3C equiv./g wet weight of flesh for Gambierdiscus and T. niloticus, respectively.

\subsection{Liquid Chromatography Coupled with Tandem Mass Spectrometry}

Analyses using liquid chromatography coupled with tandem mass spectrometry (LC-MS/MS) were conducted on freeze-dried samples of T. niloticus samples collected in July and December 2014 and November 2016.

Samples were extracted as follows: a homogenate of freeze-dried meat was extracted twice with acetone. After centrifugation, the supernatants were pooled and evaporated by rotary evaporation. The dry extract was dissolved in aqueous methanol (90:10), and a liquid-liquid partition with hexane was carried out. The $90 \%$ methanolic fraction was evaporated and then dissolved in 100\% methanol. An aliquot of this extract (first extract, FE) was filtered over $0.2 \mu \mathrm{m}$ before being analyzed by LC-MS/MS (Sciex, Kenwood, CA, USA).

The FE extract was then purified on silica cartridges Solid Phase Extraction (SPE Si) type Florosil ${ }^{\circledR}$ (Waters, Saint-Quentin, France), and the resulting fraction (SPE Si extract) evaporated under nitrogen and resuspended in $100 \%$ methanol prior to LC-MS/MS analysis.

The resulting fractions or extracts were analyzed by LC-MS/MS in MRM (multi-reaction monitoring) mode on a triple quadrupole API4000 QTrap (Sciex, Redwood, CA, USA). Biological samples and P-CTXs were analyzed using an LC-MS/MS method adapted from Yogi et al., 2011 [63]. The instrument used was an LC system (UFLC XR Nexera, Shimadzu, Kyoto, Japan) coupled to a hybrid triple quadrupole-linear ion trap mass spectrometer (API-4000Qtrap, Sciex, Kenwood, CA, USA) equipped with a turbo ${ }^{\circledR}$ ion spray interface. A 1.8- $\mu \mathrm{m} \mathrm{C}_{18}$ Zorbax Eclipse plus column $(50 \times 2.1 \mathrm{~mm}$, Agilent technologies, Santa Clara, CA, USA) was employed at $40{ }^{\circ} \mathrm{C}$ and eluted at $400 \mu \mathrm{L} / \mathrm{min}$ with a linear gradient. Eluent $\mathrm{A}$ is water, and Eluent $\mathrm{B}$ is methanol, both eluents containing $2 \mathrm{mM}$ ammonium formiate and $50 \mathrm{mM}$ formic acid. The elution gradient ran from $78-88 \%$ over $10 \mathrm{~min}$ and was held for $4 \mathrm{~min}$ before re-equilibration during $5 \mathrm{~min}$.

Mass spectrometry detection was operated in positive mode and using multiple reaction monitoring (MRM) (Analyst software, Sciex, Kenwood, CA, USA). The pseudomolecular ions $\left[\mathrm{M}+\mathrm{NH}_{4}\right]^{+}$and $[\mathrm{M}+\mathrm{H}]^{+}$were selected as precursor ions. The ions resulting in the successive losses of $\mathrm{NH}_{4}$ and/or water molecules were selected as product ions (Table 8). The MRM experiments were established by using the following source settings: curtain gas set at 25, ion spray at $5500 \mathrm{~V}$, a turbogas temperature of $300^{\circ} \mathrm{C}$, Gas 1 set at 40 and Gas 2 set at 60 psi with an entrance potential of $10 \mathrm{~V}$ and declustering potential of $105 \mathrm{~V}$.

Data processing and analysis were carried out using Analyst software (Sciex, Kenwood, CA, USA). Quantification was performed by linear calibration using P-CTX-3C standard (Wako chemicals GmbH, Neuss, Germany). To complete chromatogram profiles, a mix of standards (P-CTX-1B, P-CTX-3B, P-CTX-4A, P-CTX-4B, M-seco P-CTX-3C and 51-OH P-CTX-3C) provided by Louis Malardé Institute (ILM, Tahiti, French Polynesia) was injected in the sequence.

In addition to the detection of P-CTXs, other marine biotoxins were investigated according to methods previously described [64-66]: neurologic shellfish toxins (NSP), i.e., brevetoxins (PbTX1PbTX10), paralytic shellfish poisoning (PSP) toxins, i.e., carbamates (STX, NEO-STX, GTX1-GTX4), N-sulfocarbamoyl (GTX5, GTX6 and C1-C4) and decarbamoyls (dcSTX, dcNEO, dcGTX1-dcGTX4); diarrhetic shellfish poisoning (DSP) toxins, i.e., okadaic acid (OA), dinophysistoxins (DTXs), 
pectenotoxins (PTXs), azaspiracids (AZAs) and yessotoxins (YTXs); cyclic imines (fast action toxins (FAT)): gymnodimines (GYMs), spirolides (SPXs) and pinnatoxins (PnTXs).

Table 8. Mass spectrometer parameters.

\begin{tabular}{|c|c|c|c|c|c|}
\hline Compound & $\begin{array}{c}\text { Precursor } \\
\text { Ion (Q1) } m / z\end{array}$ & $\begin{array}{l}\text { Product Ion } \\
\text { (Q2) } \mathrm{m} / \mathrm{z}\end{array}$ & $\begin{array}{l}\text { Collision Energy } \\
\text { (CE, eV) }\end{array}$ & $\begin{array}{c}\text { Collision Exit } \\
\text { Potential (CXP, eV) }\end{array}$ & $\begin{array}{c}\text { Retention } \\
\text { Time (RT, min) }\end{array}$ \\
\hline \multirow{2}{*}{ Р-СТХ1B } & \multirow{2}{*}{1128.6} & 1093.6 & 20 & 12 & \multirow[b]{2}{*}{2.9} \\
\hline & & 1075.6 & 30 & 12 & \\
\hline \multirow{2}{*}{$\begin{array}{l}\text { P-CTX3C and } \\
\text { P-СTX3B }\end{array}$} & 1040.6 & 1005.6 & 30 & 12 & \multirow{2}{*}{11.3 and 11.5} \\
\hline & 1023.6 & 1005.6 & 20 & 12 & \\
\hline \multirow{2}{*}{$\begin{array}{l}\text { P-CTX4A and } \\
\text { P-CTX4B }\end{array}$} & 1078.6 & 1043.6 & 30 & 12 & \multirow{2}{*}{12.4 and 12.8} \\
\hline & 1061.6 & 1043.6 & 20 & 12 & \\
\hline \multirow{2}{*}{ 2,3-diOH-P-СТХ3С } & 1074.6 & 1057.6 & 30 & 12 & \\
\hline & 1057.6 & 1039.6 & 20 & 12 & \\
\hline \multirow{2}{*}{ 51-ОН-Р-СТХ3С } & 1056.6 & 1021.6 & 30 & 12 & \multirow{2}{*}{6.1} \\
\hline & 1039.6 & 1021.6 & 20 & 12 & \\
\hline \multirow{2}{*}{ M-seco-P-СТХЗС } & \multirow{2}{*}{1041.6} & 1023.6 & 30 & 12 & \multirow{2}{*}{4.6} \\
\hline & & 1005.6 & 20 & 12 & \\
\hline \multirow{2}{*}{$\mathrm{P}-\mathrm{CTX} 2$ and P-CTX3 } & \multirow{2}{*}{1112.6} & 1077.6 & 20 & 12 & \\
\hline & & 1059.6 & 30 & 12 & \\
\hline \multirow{2}{*}{$\begin{array}{c}\text { 2-OH-P-СТХ3С and } \\
\text { 3-OH-Р-СТХ3С }\end{array}$} & \multirow{2}{*}{1058.6} & 1023.6 & 30 & 12 & \multirow{2}{*}{4.8} \\
\hline & & 1005.6 & 20 & 12 & \\
\hline
\end{tabular}

Acknowledgments: The present work was supported by funds from the countries of France and French Polynesia (Contrat de Projet "Caractérisation et gestion des risques environnementaux et sanitaires liés au développement du phytoplancton ciguatérigène en Polynésie française: CARISTO-Pf" No. 7937/MSR/REC of 4 December 2015 and Arrêté No. HC/491/DIE/BPT of 30 March 2016). The authors greatly acknowledge Mrs. Stephen Yen Kai Sun and Arsène Stein from the Marine and Mining Resources Directorate (DRMM) of French Polynesia, as well as Véronique Tamarii and Stéphanie Nouel from the Sentinel Network of the Public Health Directorate for their assistance in the collection of trochus samples. The authors also greatly acknowledge Taina Revel for doing Gambierdiscus qPCR in tandem with the NOAA team, Philippe Cruchet, André Ung, Kevin Henry and Tiriana Tchong for their skillful technical assistance in field-sampling, in vitro cultures, qPCR assays and sample extractions and Tiriana Tchong for her drawings of Gambierdiscus, CTX and trochus.

Author Contributions: Mireille Chinain, Hélène Taiana Darius and Mélanie Roué conceived of and designed the study. Mireille Chinain, Hélène Taiana Darius and Clémence Mahana iti Gatti supervised and contributed actively to the field samplings. Mark W. Vandersea, R. Wayne Litaker and Patricia A. Tester assisted in the determination of Gambierdiscus cell abundance and species distribution in wild samples. Mélanie Roué and Manoella Sibat performed chemical extractions for CBA-N2a and LC-MS/MS analysis, respectively. Jérôme Viallon and Manoella Sibat conducted the CBA-N2a and LC-MS/MS analysis, respectively. Hélène Taiana Darius, Mélanie Roué and Jérôme Viallon contributed to the CBA-N2a data analysis and Manoella Sibat, Philipp Hess and Zouher Amzil to the LC-MS/MS data analysis, respectively. Hélène Taiana Darius prepared the first draft of the paper and coordinated revisions. All authors contributed to the editing of the paper.

Conflicts of Interest: The authors declare no conflict of interest.

\section{References and Note}

1. Williams, S.T.; Karube, S.; Ozawa, T. Molecular systematics of vetigastropoda: Trochidae, turbinidae and trochoidea redefined. Zool. Scr. 2008, 48, 1-24. [CrossRef]

2. Purcell, S.W.; Cheng, Y.W. Experimental restocking and seasonal visibility of a coral reef gastropod assessed by temporal modelling. Aquat. Biol. 2010, 9, 227-238. [CrossRef]

3. Lorrain, A.; Clavier, J.; Thébault, J.; Tremblay-Boyer, L.; Houlbrèque, F.; Amice, E.; Le Gof, M.; Chauvaud, L. Variability in diel and seasonal in situ metabolism of the tropical gastropod Tectus niloticus. Aquat. Biol. 2015, 23, 167-182. [CrossRef]

4. Pakoa, K.; Friedman, K.; Damlamian, H. The status of trochus (Trochus niloticus) in Tongatapu Lagoon, kingdom of Tonga. SPC Trochus Inf. Bull. 2010, 15, 3-16. 
5. Castell, L.L. Population studies of juvenile Trochus niloticus on a reef flat on the North-Eastern Queensland coast, Australia. Mar. Freshw. Res. 1997, 48, 211-217. [CrossRef]

6. Hoang, D.H.; Tuyen, H.T.; Lu, H.D. Growth rate of Trochus niloticus (1., 1767) fed different food types. SPC Trochus Inf. Bull. 2008, 14, 7-11.

7. Villanueva, R.D.; Baria, M.V.B.; de la Cruz, D.W. Effects of grazing by herbivorous gastropod (Trochus niloticus) on the survivorship of cultured coral spat. Zool. Stud. 2013, 52. [CrossRef]

8. Bour, W. Un Mollusque Nacrier du Pacifique. Biologie, Écologie et Gestion Rationnelle d'un Mollusque Nacrier du Pacifique: Le Troca (Trochus niloticus L.) de Nouvelle Calédonie; Editions de l'ORSTOM, Collection Etudes et Thèses; Institut Francais de Recherche Scientifique pour le Développement en Coopération: Paris, France, 1992; p. 174.

9. Adams, T.J.H.; Dalzell, P.J. Artisanal Fishing. In East-West Center Workshop on Marine Biodiversity; University of Hawaii: Honolulu, HI, USA, 1994; p. 19.

10. Hoang, D.H.; Tuan, V.S.; Hoa, N.X.; Sang, H.M.; Lu, H.D.; Tuyen, H.T. Experiments on using hatchery-reared Trochus niloticus juveniles for stock enhancement in Vietnam. SPC Trochus Inf. Bull. 2007, 13, 13-18.

11. Teitelbaum, A.; Friedman, K. Successes and failures in reintroducing giant clams in the Indo-Pacific region. SPC Trochus Inf. Bull. 2008, 14, 19-26.

12. Tuhumury, F.S. Dynamic model of Trochus niloticus. Linn, in resources management, in coastal area of Saparua Island, Saparua Subdistrict, Central Maluku Regency. IOSR J. Agric. Vet. Sci. 2014, 7, 33-40. [CrossRef]

13. Gillett, R. Pacific islands trochus introductions 1927-1998. SPC Trochus Inf. Bull. 2002, 9, 9-13.

14. French Polynesia. Délibération relative à la protection de certaines espèces animales marines et d'eau douce du patrimoine naturel polynésien. Journal Officiel de la Polynésie Française: Tahiti, French Polynesia, 1988.

15. Gatti, C.; Lonatti, D.; Darius, H.T.; Chinain, M. First report of a mass-poisoning outbreak following the consumption of Tectus niloticus (Gastropod) in French Polynesia: A novel pathway of Ciguatera Shellfish Poisoning? Harmful Algae News 2015, 50, 19-20.

16. Lonati, D.; Gatti, C.M.; Zancan, A.; Darius, H.T.; Fleure, M.; Chinain, M.; Buonocore, M.; Locatelli, C.A. Novel ciguatera shellfish poisoning (CSP) cluster following the consumption of Tectus niloticus (gastropod) in Nuku Hiva (Marquesas Archipelago, French Polynesia). In Proceedings of the 35th International Congress of the European Association of Poisons Centres and Clinical Toxicologists (EAPCCT), St Julian's, Malta, 26-29 May 2015; Clinical Toxicology: St Julian's, Malta, 2015; Volume 53, p. 278.

17. Chinain, M.; Darius, H.T.; Ung, A.; Cruchet, P.; Wang, Z.; Ponton, D.; Laurent, D.; Pauillac, S. Growth and toxin production in the ciguatera-causing dinoflagellate Gambierdiscus polynesiensis (Dinophyceae) in culture. Toxicon 2010, 56, 739-750. [CrossRef] [PubMed]

18. Lehane, L.; Lewis, R.J. Ciguatera: Recent advances but the risk remains. Int. J. Food Microbiol. 2000, 61, 91-125. [CrossRef]

19. Laurent, D.; Kerbrat, A.S.; Darius, H.T.; Rossi, F.; Yeeting, B.; Haddad, M.; Golubic, S.; Pauillac, S.; Chinain, M. Ciguatera shellfish poisoning (CSP): A new ecotoxicological phenomenon from cyanobacteria to humans via giant clams. In Food Chains: New Research; Melissa, A.J., Danielle, W.M., Eds.; Nova Science Publishers, Inc.: NewYork, NY, USA, 2012; Chapter 1; pp. 1-43.

20. Chinain, M.; Darius, H.T.; Ung, A.; Tchou Fouc, M.; Revel, T.; Cruchet, P.; Pauillac, S.; Laurent, D. Ciguatera risk management in French Polynesia: The case study of Raivavae Island (Australes Archipelago). Toxicon 2010, 56, 674-690. [CrossRef] [PubMed]

21. Pawlowiez, R.; Darius, H.T.; Cruchet, P.; Rossi, F.; Caillaud, A.; Laurent, D.; Chinain, M. Evaluation of seafood toxicity in the Australes Archipelago (French Polynesia) using the neuroblastoma cell-based assay. Food Addit. Contam. Part A 2013, 30, 567-586. [CrossRef] [PubMed]

22. Rongo, T.; van Woesik, R. Ciguatera poisoning in Rarotonga, southern Cook Islands. Harmful Algae 2011, 10, 345-355. [CrossRef]

23. Roué, M.; Darius, H.T.; Picot, S.; Ung, A.; Viallon, J.; Gaertner-Mazouni, N.; Sibat, M.; Amzil, Z.; Chinain, M. Evidence of the bioaccumulation of ciguatoxins in giant clams (Tridacna maxima) exposed to Gambierdiscus spp. cells. Harmful Algae 2016, 57, 78-87. [CrossRef]

24. European Food Safety Authority (EFSA). Scientific opinion on marine biotoxins in shellfish-Emerging toxins: Ciguatoxin group. EFSA J. 2010, 1627, 1-38. 
25. Food and Drug Administration. Fish and Fishery Products Hazards and Control Guidance. Available online: https:/ / www.fda.gov/food/guidanceregulation/guidancedocumentsregulatoryinformation/ seafood/ucm2018426.htm (accessed on 13 December 2017).

26. Rehmann, N.; Hess, P.; Quilliam, M.A. Discovery of new analogs of the marine biotoxin azaspiracid in blue mussels (Mytilus edulis) by ultra-performance liquid chromatography/tandem mass spectrometry. Rapid Commun. Mass Spectrom. 2008, 22, 549-558. [CrossRef] [PubMed]

27. Shumway, S.E. Phycotoxin-related shellfish poisoning: Bivalve molluscs are not the only vectors. Rev. Fish. Sci. 1995, 3, 1-31. [CrossRef]

28. Negri, A.; Llewellyn, L. Comparative analyses by HPLC and the sodium channel and saxiphilin $3 \mathrm{H}$-saxitoxin receptor assays for paralytic shellfish toxins in crustaceans and molluscs from tropical North West Australia. Toxicon 1998, 36, 283-298. [CrossRef]

29. Deeds, J.R.; Landsberg, J.H.; Etheridge, S.M.; Pitcher, G.C.; Longan, S.W. Non-traditional vectors for paralytic shellfish poisoning. Mar. Drugs 2008, 6, 308-348. [CrossRef] [PubMed]

30. Costa, P.R.; Costa, S.T.; Braga, A.C.; Rodrigues, S.M.; Vale, P. Relevance and challenges in monitoring marine bio toxins in nonbivalve vectors. Food Control 2017, 76, 24-33. [CrossRef]

31. Darius, H.T.; Ponton, D.; Revel, T.; Cruchet, P.; Ung, A.; Tchou Fouc, M.; Chinain, M. Ciguatera risk assessment in two toxic sites of French Polynesia using the receptor-binding assay. Toxicon 2007, 50, 612-626. [CrossRef] [PubMed]

32. Pisapia, F.; Holland, W.C.; Hardison, D.R.; Litaker, R.W.; Fraga, S.; Nishimura, T.; Adachi, M.; Nguyen-Ngoc, L.; Séchet, V.; Amzil, Z.; et al. Toxicity screening of 13 Gambierdiscus strains using neuro-2a and erythrocyte lysis bioassays. Harmful Algae 2017, 63, 173-183. [CrossRef] [PubMed]

33. Roué, M.; Darius, H.T.; Viallon, J.; Ung, A.; Gatti, C.; Harwood, T.; Chinain, M. Application of solid phase adsorption toxin tracking (SPATT) devices for the field detection of Gambierdiscus toxins. Harmful Algae 2018, 71, 40-49. [CrossRef]

34. Holland, W.C.; Litaker, W.; Tomas, C.; Kibler, S.; Place, A.; Davenport, E.; Tester, P. Differences in the toxicity of six Gambierdiscus (Dinophyceae) species measured using an in vitro human erythrocyte lysis assay. Toxicon 2013, 65, 15-33. [CrossRef] [PubMed]

35. Kohli, G.S.; Murray, S.A.; Neilan, B.A.; Rhodes, L.L.; Harwood, T.D.; Smith, K.F.; Meyer, L.; Capper, A.; Brett, S.; Hallegraeff, G.M. High abundance of the potentially maitotoxic dinoflagellate Gambierdiscus carpenteri in temperate waters of New South Wales, Australia. Harmful Algae 2014, 39, 134-145. [CrossRef]

36. Pisapia, F.; Sibat, M.; Herrenknecht, C.; Lhaute, K.; Gaiani, G.; Ferron, P.-J.; Fessard, V.; Fraga, S.; Nascimento, S.M.; Litaker, R.W.; et al. Maitotoxin-4, a novel MTX analog produced by Gambierdiscus excentricus. Mar. Drugs 2017, 15, 220. [CrossRef] [PubMed]

37. Litaker, R.W.; Holland, W.C.; Hardison, D.R.; Pisapia, F.; Hess, P.; Kibler, S.R.; Tester, P.A. Ciguatoxicity of Gambierdiscus and Fukuyoa species from the Caribbean and Gulf of Mexico. PLoS ONE 2017, 12, e0185776. [CrossRef] [PubMed]

38. Chinain, M.; Germain, M.; Deparis, X.; Pauillac, S.; Legrand, A.-M. Seasonal abundance and toxicity of the dinoflagellate Gambierdiscus spp. (Dinophyceae), the causative agent of ciguatera in Tahiti, French Polynesia. Mar. Biol. 1999, 135, 259-267. [CrossRef]

39. Dickey, R.W.; Plakas, S.M. Ciguatera: A public health perspective. Toxicon 2010, 56, 123-136. [CrossRef] [PubMed]

40. Litaker, R.W.; Vandersea, M.W.; Faust, M.A.; Kibler, S.R.; Nau, A.W.; Holland, W.C.; Chinain, M.; Holmes, M.J.; Tester, P.A. Global distribution of ciguatera causing dinoflagellates in the genus Gambierdiscus. Toxicon 2010, 56, 711-730. [CrossRef] [PubMed]

41. Kibler, S.R.; Litaker, R.W.; Holland, W.C.; Vandersea, M.W.; Tester, P.A. Growth of eight Gambierdiscus (Dinophyceae) species: Effects of temperature, salinity and irradiance. Harmful Algae 2012, 19, 1-14. [CrossRef]

42. Yoshimatsu, T.; Yamaguchi, H.; Iwamoto, H.; Nishimura, T.; Adachi, M. Effects of temperature, salinity and their interaction on growth of Japanese Gambierdiscus spp. (Dinophyceae). Harmful Algae 2014, 35, $29-37$. [CrossRef]

43. Xu, Y.; Richlen, M.L.; Liefer, J.D.; Robertson, A.; Kulis, D.; Smith, T.B.; Parsons, M.L.; Anderson, D.M. Influence of environmental variables on Gambierdiscus spp. (Dinophyceae) growth and distribution. PLoS ONE 2016, 11, e0153197. [CrossRef] [PubMed] 
44. Sparrow, L.; Momigliano, P.; Russ, G.R.; Heimann, K. Effects of temperature, salinity and composition of the dinoflagellate assemblage on the growth of Gambierdiscus carpenteri isolated from the great barrier reef. Harmful Algae 2017, 65, 52-60. [CrossRef] [PubMed]

45. John, U.; Tillmann, U.; Hülskötter, J.; Alpermann, T.J.; Wohlrab, S.; Van de Waal, D.B. Intraspecific facilitation by allelochemical mediated grazing protection within a toxigenic dinoflagellate population. Proc. R. Soc. B Biol. Sci. 2015, 282. [CrossRef] [PubMed]

46. García-Portela, M.; Riobó, P.; Franco, J.M.; Bañuelos, R.M.; Rodríguez, F. Genetic and toxinological characterization of north atlantic strains of the dinoflagellate Ostreopsis and allelopathic interactions with toxic and non-toxic species from the genera Prorocentrum, Coolia and Gambierdiscus. Harmful Algae 2016, 60, 57-69. [CrossRef] [PubMed]

47. Rhodes, L.; Towers, N.; Briggs, L.; Munday, R.; Adamson, J. Uptake of palytoxin-like compounds by shellfish fed Ostreopsis siamensis (Dinophyceae). N. Z. J. Mar. Freshw. Res. 2002, 36, 631-636. [CrossRef]

48. Rolland, J.L.; Pelletier, K.; Masseret, E.; Rieuvilleneuve, F.; Savar, V.; Santini, A.; Amzil, Z.; Laabir, M. Paralytic toxins accumulation and tissue expression of a-amylase and lipase genes in the pacific oyster Crassostrea gigas fed with the neurotoxic dinoflagellate Alexandrium catenella. Mar. Drugs 2012, 10, 2519-2534. [CrossRef] [PubMed]

49. Jauffrais, T.; Marcaillou, C.; Herrenknecht, C.; Truquet, P.; Sechet, V.; Nicolau, E.; Tillmann, U.; Hess, P. Azaspiracid accumulation, detoxification and biotransformation in blue mussels (Mytilus edulis) experimentally fed Azadinium spinosum. Toxicon 2012, 60, 582-595. [CrossRef] [PubMed]

50. Jauffrais, T.; Kilcoyne, J.; Herrenknecht, C.; Truquet, P.; Sechet, V.; Miles, C.O.; Hess, P. Dissolved azaspiracids are absorbed and metabolized by blue mussels (Mytilus edulis). Toxicon 2013, 65, 81-89. [CrossRef] [PubMed]

51. Haberkorn, H.; Lambert, C.; Le Goic, N.; Quere, C.; Bruneau, A.; Riso, R.; Auffret, M.; Soudant, P. Cellular and biochemical responses of the oyster Crassostrea gigas to controlled exposures to metals and Alexandrium minutum. Aquat. Toxicol. 2014, 147, 158-167. [CrossRef] [PubMed]

52. Laurent, D.; Kerbrat, A.-S.; Darius, H.T.; Girard, E.; Golubic, S.; Benoit, E.; Sauviat, M.-P.; Chinain, M.; Molgo, J.; Pauillac, S. Are cyanobacteria involved in Ciguatera Fish Poisoning-like outbreaks in new Caledonia? Harmful Algae 2008, 7, 827-838. [CrossRef]

53. Mak, Y.L.; Wai, T.-C.; Murphy, M.B.; Chan, W.H.; Wu, J.J.; Lam, J.C.W.; Chan, L.L.; Lam, P.K.S. Pacific ciguatoxins in food web components of coral reef systems in the Republic of Kiribati. Environ. Sci. Technol. 2013, 47, 14070-14079. [CrossRef] [PubMed]

54. Silva, M.; Rodriguez, I.; Barreiro, A.; Kaufmann, M.; Neto, A.I.; Hassouani, M.; Sabour, B.; Alfonso, A.; Botana, L.M.; Vasconcelos, V. First report of ciguatoxins in two starfish species : Ophidiaster ophidianus and Marthasterias glacialis. Toxins 2015, 7, 3740-3757. [CrossRef] [PubMed]

55. Kerbrat, A.-S.; Darius, H.T.; Pauillac, S.; Chinain, M.; Laurent, D. Detection of ciguatoxin-like and paralysing toxins in Trichodesmium spp. from New Caledonia lagoon: New Caledonia tropical lagoons: An overview of multidisciplinary investigations. Mar. Pollut. Bull. 2010, 61, 360-366. [CrossRef] [PubMed]

56. Mejean, A.; Peyraud-Thomas, C.; Kerbrat, A.S.; Golubic, S.; Pauillac, S.; Chinain, M.; Laurent, D. First identification of the neurotoxin homoanatoxin-a from mats of Hydrocoleum lyngbyaceum (marine cyanobacterium) possibly linked to giant clam poisoning in New Caledonia. Toxicon 2010, 56, 829-835. [CrossRef] [PubMed]

57. Kerbrat, A.-S.; Amzil, Z.; Pawlowiez, R.; Golubic, S.; Sibat, M.; Darius, H.T.; Chinain, M.; Laurent, D. First evidence of palytoxin and 42-hydroxy-palytoxin in the marine cyanobacterium Trichodesmium. Mar. Drugs 2011, 9, 543-560. [CrossRef] [PubMed]

58. Villeneuve, A.; Laurent, D.; Chinain, M.; Gugger, M.; Humbert, J.F. Molecular characterization of the diversity and potential toxicity of cyanobacterial mats in two tropical lagoons in the South Pacific ocean. J. Phycol. 2012, 48, 275-284. [CrossRef] [PubMed]

59. Tester, P.A.; Kibler, S.R.; Holland, W.C.; Usup, G.; Vandersea, M.W.; Leaw, C.P.; Teen, L.P.; Larsen, J.; Mohammad-Noor, N.; Faust, M.A.; et al. Sampling harmful benthic dinoflagellates: Comparison of artificial and natural substrate methods. Harmful Algae 2014, 39, 8-25. [CrossRef]

60. Vandersea, M.W.; Kibler, S.R.; Holland, W.C.; Tester, P.A. Development of semi-quantitative pcr assays for the detection and enumeration of Gambierdiscus species (Gonyaulacales, Dinophyceae). J. Phycol. 2012, 48, 902-915. [CrossRef] [PubMed] 
61. Nicolas, J.; Hendriksen, P.J.M.; Gerssen, A.; Bovee, T.F.; Rietjens, I.M. Marine neurotoxins: State of the art, bottlenecks, and perspectives for mode of action based methods of detection in seafood. Mol. Nutr. Food Res. 2014, 58, 87-100. [CrossRef] [PubMed]

62. Caillaud, A.; Eixarch, H.; de la Iglesia, P.; Rodriguez, M.; Dominguez, L.; Andree, K.B.; Diogène, J. Towards the standardisation of the neuroblastoma (neuro-2a) cell-based assay for ciguatoxin-like toxicity detection in fish: Application to fish caught in the Canary Islands. Food Addit. Contam. 2012, 29, 1000-1010. [CrossRef] [PubMed]

63. Yogi, K.; Oshiro, N.; Inafuku, Y.; Hirama, M.; Yasumoto, T. Detailed LC-MS/MS analysis of ciguatoxins revealing distinct regional and species characteristics in fish and causative alga from the Pacific. Anal. Chem. 2011, 83, 8886-8891. [CrossRef] [PubMed]

64. Amzil, Z.; Sibat, M.; Royer, F.; Masson, N.; Abadie, E. Report on the first detection of pectenotoxin-2, spirolide-a and their derivatives in French shellfish. Mar. Drugs 2007, 5, 168-179. [CrossRef] [PubMed]

65. Amzil, Z.; Sibat, M.; Royer, F.; Savar, V. First report on azaspiracid and yessotoxin groups detection in French shellfish. Toxicon 2008, 52, 39-48. [CrossRef] [PubMed]

66. Hess, P.; Abadie, E.; Hervé, F.; Berteaux, T.; Séchet, V.; Aráoz, R.; Molgó, J.; Zakarian, A.; Sibat, M.; Rundberget, T.; et al. Pinnatoxin G is responsible for atypical toxicity in mussels (Mytilus galloprovincialis) and clams (Venerupis decussata) from ingril, a french mediterranean lagoon. Toxicon 2013, 75, 16-26. [CrossRef] [PubMed]

(C) 2017 by the authors. Licensee MDPI, Basel, Switzerland. This article is an open access article distributed under the terms and conditions of the Creative Commons Attribution (CC BY) license (http:/ / creativecommons.org/licenses/by/4.0/). 